\title{
Process, performance and pollution potential: A review of septic tank - soil absorption systems
}

\author{
C. D. Beal ${ }^{A}$, E. A. Gardner ${ }^{B}$, N. W. Menzies $^{C}$, \\ ${ }^{A}$ School of Land \& Food Sciences, University of Queensland; and Coastal CRC, Indooroopilly, Qld \\ ${ }^{B}$ Qld Department of Natural Resources, Mines \& Energy; and Coastal CRC, Indooroopilly, Qld \\ ${ }^{C}$ School of Land \& Food Sciences, University of Queensland, St Lucia, Qld 4073
}

\begin{abstract}
On-site wastewater treatment and dispersal systems (OWTS) are used in non-sewered populated areas in Australia to treat and dispose of household wastewater. The most common OWTS in Australia is the septic tank - soil absorption system (SAS) which relies on the soil to treat and disperse effluent. The mechanisms governing purification and hydraulic performance of a SAS are complex and have been shown to be highly influenced by the biological zone (biomat) which develops on the soil surface within the trench or bed. Studies suggest that removal mechanisms in the biomat zone, primarily adsorption and filtering, are important processes in the overall purification abilities of a SAS. There is growing concern that poorly functioning OWTS are impacting upon the environment. Though, to date, only a few investigations have been able to demonstrate pollution of waterways by on-site systems.
\end{abstract}

In this paper we review some key hydrological and biogeochemical mechanisms in SAS, and the processes leading to hydraulic failure. The nutrient and pathogen removal efficiencies in soil absorption systems are also reviewed, and a critical discussion of the evidence of failure and environmental and public health impacts arising from SAS operation is presented. Future research areas identified from the review include the interactions between hydraulic and treatment mechanisms, and the biomat and sub-biomat zone gas composition and its role in effluent treatment.

Additional keywords: biomat, LTAR, modelling, nutrients, pathogens, on-site systems, wastewater 


\section{Introduction}

On-site wastewater treatment and dispersal systems (OWTS) are used in non-sewered populated areas in $20 \%$ of Australian households to treat and dispose of household wastewater. The most common OWTS in Australia is the septic tank - soil absorption system (SAS). Wastewater undergoes primary treatment in the septic tank via sedimentation and anaerobic digestion. Secondary treatment of the septic tank effluent occurs within the trenches or beds and surrounding soil (Figure 1). A SAS utilises the soil as the medium to treat and disperse effluent originating from the septic tank.

Fig 1.

Unlike alternative OWTS, the soil absorption system relies solely on the natural biogeochemical processes that occur in soil to assimilate various effluent pollutants. The advantage that this method has over other on-site systems is its relative simplicity, low cost and, if designed and constructed properly, treatment capability. The limitations of SAS relate to the inherent variability and heterogeneity of soil and soil biogeochemical processes. With aerated wastewater treatment systems (AWTS) the treatment processes (aeration, clarification, dispersion) can be directly controlled or regulated after system installation. Conversely, apart from septic tank inspections, the operation of a SAS is largely left to natural processes below the soil's surface. Consequently, appropriate design, construction, and maintenance, based on prior knowledge of the site and soil conditions, are crucial for the sustainable and successful operation of these systems. So it follows that an understanding of the processes that drive a SAS is essential for design and installation, and management in general. Nevertheless, success will not be achieved for every single system that has been designed, constructed and 
maintained properly; the factors required to achieve that success are too numerous and too varied. However, substantial improvement to the current sustainability of SAS is more likely to occur as a result of informed and well-considered management.

The provenance of the OWTS regulatory criteria has placed an emphasis on reducing health risks associated with OWTS. The progression of the on-site treatment industry, in terms of the use of new technologies and the introduction of performance-based criteria, has been held back by its "public health heritage" (Otis 1991). This has resulted in often conservative and prescriptive criteria set by the responsible regulatory body. In the United States, SAS are the predominant on-site system with approximately 20 million systems in use. The USEPA response to Congress on the long-term viability of on-site systems, neatly summarises their point-of-view: “Adequately managed decentralized wastewater treatment systems are a costeffective and long-term option for meeting public health and water quality goals, particularly in less densely populated areas.” (USEPA 1997). Despite this, SAS continue to have a mixed reputation in the industry and with the general public, and can be likened to "Dr Jekyll and $\mathrm{Mr}$ Hyde” in terms of its unpredictable and variable treatment efficiency and failure rates.

Some SAS can operate for many years with no discernable failure (either surcharge or groundwater impacts), while others can fail within weeks of installation, potentially resulting in adverse environmental and public health effects (and economic impacts to the owner). Yet, the evidence to support the argument that SAS cause widespread and serious pollution to surface and more commonly groundwaters, is by no means conclusive. 
This paper begins with a review of some key hydrological and biogeochemical mechanisms in SAS including the processes leading to hydraulic failure. Following this, the treatment capabilities of the SAS are discussed drawing on previous investigations. A critical review of the contrasting findings of the contamination potential of septic trench effluent is presented. The paper concludes with a discussion of the key areas of further research in the sustainable management of soil-based wastewater treatment systems.

\section{Hydraulic processes in soil absorption systems}

The mechanisms governing purification and hydraulic performance of a SAS are complex and have been shown to be highly influenced by the biological zone (biomat) or 'clogging layer' which develops on the soil surface within the trench (Bouma 1975; Siegrist and Boyle 1987). The biomat generally has a low hydraulic conductivity. Bouma (1975) calculated values of approximately $0.6 \mathrm{~mm} /$ day for clay soils and $2 \mathrm{~mm} /$ day for sandy soils.

The hydraulic conductivity of the biomat reduces over time with a concomitant increase in biomat resistance. With this increase in resistance, flow through the biomat is reduced to an extent that effluent can build up above the biomat while the underlying soil remains unsaturated (Kristiansen 1981a). It is the unsaturated flow characteristics (K( $\Psi)$ ) of the soil and the resistance properties of the biomat that govern the long-term flow rates though the biomat and sub-biomat zone (Huntzinger Beach and McCray 2003).

A crust-capped soil, as is the case in a mature SAS, has been shown to behave as a "selfadjusting” system, where a steady-state infiltration rate and soil moisture profile develops over 
time (Hillel 1980). This steady-state is reached when sub-biomat soil matric potentials ( $\Psi$ ) create a gradient across the biomat, and the unsaturated hydraulic conductivity below the biomat allows a state of equal flux through both the biomat and unsaturated zones (Hillel 1980). This condition can be expressed as:

$$
Q_{b}=Q_{u}=K_{b}\left(\frac{d H}{d Z}\right)_{b}=K_{u}\left(\frac{d H}{d Z}\right)_{u}
$$

where $Q_{b}$ is the steady-state flux through the biomat (m/day), $Q_{u}$ is the steady-state flow through the unsaturated zone below the biomat $(\mathrm{m} / \mathrm{d}), K_{b}$ is the biomat hydraulic conductivity $(\mathrm{m} / \mathrm{d}),(d H / d Z)_{b}$ the biomat hydraulic gradient, $K_{u}$ the unsaturated hydraulic conductivity (m/d) and $(d H / d Z)_{u}$ the hydraulic gradient of the unsaturated sub-biomat zone.

Low flow rates in absorption systems are not exclusively a result of the interaction between unsaturated soil hydraulic conductivity and biomat resistance. Dispersion or swelling in sodic soils, resulting from low electrical conductivity and high sodium absorption ratio effluent applications, can substantially decrease soil hydraulic conductivity (Halliwell et al. 2001; Patterson 2001). In this case the steady-state flow would be less easily predicted as a factor solely of biomat zone hydraulic resistance.

The resultant $Q$ in equation 1 is the long-term steady-state flux $(\mathrm{m} / \mathrm{d})$ at which, theoretically, a SAS can continue to accept effluent without hydraulic failure occurring. This flux value is also known as the long-term acceptance rate (LTAR), with units of $\mathrm{mm} /$ day or $\mathrm{L} / \mathrm{m}^{2} / \mathrm{day}$. The LTAR is a key parameter used in the Australian and New Zealand Standard AS1547:2000 to 
calculate the soil surface area and length of trench required to ensure SAS are not overloaded. The LTAR curve was originally formulated from the work of Brouwer and Bujega (1983) who carried out a land capability assessment for septic systems in Victoria. The most significant aspect of the report was the development of a curve which plotted the relationship of soil hydraulic conductivity with LTAR of effluent into soil (Brouwer and Bugeja, 1983). This LTAR curve became the basis for sizing recommendations, e.g. trench length/equivalent person, in the Australian Standard publication AS1547:1994 (Standards Australia 1994) and Australian and New Zealand Standard - AS/NZS 1547: 2000 (Standards Australia and Standards New Zealand 2000). Unfortunately, there were a number of limitations with the study, including soil solution sampling difficulties, limited replications, questionable suitability of sites, and unusually dry weather. As a result of these difficulties, only one pair of septic absorption trenches was investigated (Brouwer and Bugeja 1983). The authors acknowledged these issues and emphasised that a more representative dataset would be required to substantiate the conclusions and recommendations made in their report.

\section{Biomat zone genesis and development}

Biomat zone genesis and development is a dynamic process which can be influenced by physical, biological and chemical processes. The dominance of any one process can be difficult to isolate as they often occur concurrently (Baveye et al. 1998). Biomat genesis is generally characterised by an initial physical clogging of the pores in the infiltrative surface of the native soil (Otis 1984; Siegrist et al. 1991). Anaerobic biological activity has commonly been identified as the main subsequent clogging process (Siegrist and Boyle 1987; Tyler and 
Converse 1994). Clogging usually occurs within the first few months of full operation of a SAS (Kristiansen 1981a).

The main factors influencing the initial clogging and biomat zone genesis are the wastewater characteristics (suspended solids (SS), biochemical oxygen demand (BOD), and loading rate. Other factors include poor construction practices (smearing of the trench bottom), electrical conductivity, sodium absorption ratio and underlying soil structural and textural properties (Otis 1984). Stimulated by a favourable environment (eg. anaerobic conditions, high humidity and moisture) in the initially clogged soil, biological activity then plays a significant role in long-term growth of the biomat zone (Bouma 1979).

Based on marked reductions in infiltration rate over time, three distinct phases of soil clogging leading to reduction in infiltration rate have commonly been observed (Allison 1947; Jones and Lee 1979; Otis 1984; Siegrist and Boyle 1987). A general pattern of infiltration rate decline adapted from Otis (1984) is presented in Figure 2.

\section{Fig. 2}

Phase I of biomat zone development is characterised by a sharp reduction in infiltration rates following effluent application. The initial clogging mechanisms can be attributed to several factors. These include physical straining of organic materials and suspended particulates contained in the wastewater and entrapment of gases (Bouma 1979; Baveye et al. 1998; Siegrist et al. 2000). These processes act to block soil pores in the infiltrative surface, thus 
impeding pore connectivity and flow rate through to the unsaturated zone beneath the absorption system.

Following a sharp reduction in the infiltrative rate during phase I, a more gradual decrease in infiltration rate has been observed (Jones and Lee 1979; Otis 1984; Siegrist and Boyle 1987). Biological activity stimulated by changes to soil conditions created during phase I (eg. low aeration status, high humidity and moisture levels) is believed to be the predominant mechanism of clogging in this second phase (Frankenberger et al. 1979; Siegrist and Boyle 1987; Ronner and Wong 1998; van Cuyk et al. 2001b).

The third phase of biomat zone development is represented by low infiltration rates where some researchers have observed an equilibrium state (i.e. LTAR) to evolve. During this phase accumulation of clogging materials at the biomat's surface is balanced out by die-off and sloughing of clogging material at the bottom (McGauhney and Winneberger 1964; Bouma et al. 1974; Siegrist 1987; Jenssen and Krogstad 1988; Mamedov and Levy 2001). Once established, factors influencing long-term growth of the biomat zone include hydraulic (L/ $\mathrm{m}^{2} /$ day) and organic loading rates (i. e. cumulative BOD and suspended solid), dosing regime (i.e pressure versus gravity) (Rice 1974; Siegrist and Boyle 1987; Stevik et al. 1999), aeration status of the infiltrative surface (De Vries 1972; Kristiansen 1981a; Siegrist and Boyle 1987) and the underlying soil biogeochemical properties (Bouma 1975; Kropf et al. 1977). Additionally, the temperature of the wastewater being applied to the soil is an influential factor on biomat development (Kristiansen 1981a; Ronner and Wong 1998), with cooler temperatures generally promoting greater biomat development (De Vries 1972; Ronner and Wong 1998). 
Seasonal or infrequent use of SAS has also been shown to influence biomat development with only partial growth, or even the absence of a biomat, occurring from infrequent use (Postma et al. 1992).

\section{Predicting Long-term Acceptance Rates of SAS}

The hydraulic effects of the biomat zone on LTAR $(Q)$ can be predicted if the resistance of the biomat $\left(R_{b}\right)$ and the unsaturated hydraulic conductivity characteristics, $K(\Psi)$ of the underlying soil are known. Bouma (1975) showed that the hydraulic conductivity of the biomat $\left(K_{b}\right)$ is a function of both $R_{b}$ and the biomat zone thickness $\left(Z_{b}\right)$.

Biomat resistance is the product of the inverse of $K_{b}$ and the effective thickness of the biomat $\left(Z_{b}\right)$. Taking $K_{b}(d H / d Z)_{b}$ from Equation 1 and assuming a steady infiltrating soil profile where the hydraulic gradient approximates unity, we can write:

$$
Q_{u}=K(\psi)=K_{b}\left(\frac{d H}{d Z}\right)_{b}
$$

Fig. 3.

$$
=K_{b}\left(\frac{H_{o}+\psi+Z_{b}}{Z_{b}}\right)
$$

By rearranging this, the hydraulic resistance $\left(R_{b}\right)$ of the biomat can be determined:

$$
\frac{K(\psi)}{H_{O}+\psi+Z_{b}}=\frac{K_{b}}{Z_{b}} \equiv \frac{1}{R_{b}}
$$


where $\mathrm{K}(\Psi)$ is the unsaturated hydraulic conductivity of the sub-biomat zone as a function of soil moisture potential, and $H_{o}$ is the positive hydraulic head on top of the biomat. A definition diagram of Equations 1 and 2 is presented in Figure 3.

Bouma (1975) calculated $R_{b}$ from measured soil potentials below trenches and reported ranges from 5-7 days for sands, 150 days for silt loams and 45-65 days for clays and silty clays. The variation in values was attributed to differences in porosity, structural instability and biological activity between soils. The wetted perimeter or lower boundary of the saturated biomat is likely to be less abrupt in sandier soils compared with the finer-textured soils. This may have affected the tensiometer readings and hence the calculated $R_{b}$ values reported in Bouma (1975), particularly if the position of the tensiometers in the soil profile was the same for each soil type.

Beal et al. (2004a) used Equation 2 to predict the effect of increasing $R b$ on flow rates for various Australian soils. Measured moisture retention characteristics (K- $\Psi$ ) taken from the literature (Forrest et al. 1985) were used to predict steady-state fluxes for various biomat resistances and soil textures. The predicted effect of $R_{b}$ on LTAR is illustrated in Figure 4.

Fig. 4.

The results from Beal et al (2004a) were similar to those of other studies (e.g. Magdoff and Bouma 1974; Huntzinger Beach and McCray 2003) in that a 2 to 3 order of magnitude variation in saturated hydraulic conductivity between soils collapsed to a one order of magnitude variation in LTAR. Sidewall exfiltration of effluent above the ponded biomat was not included in the prediction, thus the LTAR were likely to be conservative. 
The area of sidewall that has no impedance from a biomat zone can be referred to as the exfiltration zone and has been shown to be an important pathway for effluent under episodic peak loadings (Beal et al. 2004b). There are a limited number of studies modelling unsaturated flow in SAS (e.g Janni et al. 1980; Hansen and Mansell 1986; Huntzinger Beach and McCray 2003). Even less widely reported is the specific partitioning of biomat zone and non-biomat zone flow in SAS. A study by Brouwer et al. (1979) found flow through the sidewall to be greater than bottom flow in some texture-contrast soils (e.g Kurosols) in Victoria. This conclusion was drawn from field measurement of matric potentials below and adjacent to trenches and the ponded height of effluent in the trenches. The infiltration rate through the sidewalls was calculated at $35 \mathrm{~mm} /$ day, however it is not clear if sidewall flow was through a biomat zone. Huntzinger Beach and McCray (2003) used HYDRUS-2D to predict unsaturated flow within SAS, and described a strong relationship between the biomat zone hydraulic properties, and the steady-state (long-term) infiltration rates within the unsaturated zone. The model assumed that all flow occurred through either the trench bottom or trench sidewall biomat layer, thus precluding the opportunity to predict flow dynamics for the remainder of the trench sidewall.

\section{Predicting biomat zone development}

Although factors influencing biomat development are generally well-known, predicting biomat development itself is difficult. Predicting biomat growth, and thus infiltration rate decline, would allow greater knowledge of the hydraulic capacity and likely treatment efficacy of SAS in various soil types. A clear relationship has been identified between organic loading rate into 
the trench (i.e. BOD and SS) and the rate and extent of biomat development (Laak 1986; Siegrist and Boyle 1987). Drawing from this, the concept of pretreating septic tank effluent prior to dispersal into trenches has been investigated, with researchers generally agreeing that this improves the longevity of SAS by inhibiting excessive biomat growth (Laak 1970; Siegrist and Boyle 1987; Converse et al. 1998; Harrison et al. 2000; Potts et al. 2004). Some models have been proposed to quantify biomat development as a function of organic loading rates (Laak 1986; Siegrist 1987). These models have provided a useful basis for predicting biomat development and hence LTAR of SAS. However, the applicability of these models is limited to the specific set of experimental design conditions and wastewater quality associated with the particular study. Consequently, they are unlikely to be reproducible for general estimations of biomat development. (Laak 1986) describes a cube root relationship between infiltration rate, trench (bottom) area and organic loading rate by:

$$
A_{A}=A_{s}\left[\left(B O D_{5}+T S S\right) / 250\right]^{1 / 3}
$$

where $A_{A}$ is the adjusted area required $\left(\mathrm{m}^{2}\right), A_{S}$ is the area required for a standard septic system $\left(\mathrm{m}^{2}\right), \mathrm{BOD}_{5}$ is the five day biochemical oxygen demand $(\mathrm{mg} / \mathrm{L})$, and TSS the total suspended solids (mg/L). Soil absorption trench design may not be applicable using this relationship as Equation 3 was derived from soil column experiments where highly pre-treated effluent (i.e. low BOD and SS concentrations) was used. Additionally, only permeable soils were used in the soil column experiments.

Siegrist and Boyle (1987), using cumulative organic loading rates, also developed a logistic model formulated from a basic sigmoidal curve function of infiltration rate over time: 


$$
I R_{t}=241 * \frac{\left\{\exp \left[2.63-5.70(t B O D)+41.08(T S S)-0.048\left(t B O D^{*} T S S\right)\right]\right\}}{\{1+\exp [2.63-5.70(t B O D)+41.08(T S S)-0.048(t B O D * T S S)]\}}
$$

where $I R_{t}$ is the infiltration rate at time, $\mathrm{t}(\mathrm{cm} /$ day), tBOD is the cumulative density loadings $\left(\mathrm{kg} / \mathrm{m}^{2}\right)$ of total BOD (carbonaceous BOD and nitrogenous BOD), and TSS is total suspended solids $\left(\mathrm{kg} / \mathrm{m}^{2}\right)$. This model suggests that, ultimately, the infiltration rate would approach zero with continual effluent loading (containing BOD and SS). Although Equation 4 considers cumulative density loadings of organic and inorganic fractions in septic tank effluent, it does not account for the dynamically bioactive nature of the biomat zone.

Weintraub et al. (2002) developed a biozone model that considered respiration, mortality and growth of bacteria in the biomat zone as a function of organic matter. The strength of this model is the incorporation of soil physical parameters such as water content and porosity, along with the biological components. However, the link between soil matric potential and unsaturated hydraulic conductivity below the biomat is not evident. Also absent is the key parameter of biomat resistance (thickness / hydraulic conductivity of the biomat). The absence of $\mathrm{K}(\Psi)$ as an input parameter weakens the model's predictions of biozone resistance effects.

\section{Overview of treatment performance of SAS}

The quality of septic tank effluent is highly variable (Table 1). The least variable of the key effluent pollutants is faecal coliforms which have been consistently reported at concentrations between $10^{5}$ and $10^{7}$ colony forming units (cfu)/mL (Brandes 1978; van Cuyk et al. 2001a; USEPA 2002). Virus concentrations in septic tank effluent are less widely reported but could 
be expected to be in the range $10^{5}$ to $10^{6}$ counts/100mL F-RNA bacteriophages (viral indicators) (Pang et al. 2003).

Table 1. Septic tank effluent quality for key pollutants

Studies suggest that nutrient and pathogen removal mechanisms in the biomat zone, primarily adsorption and filtering, are important processes in the overall purification abilities of a SAS. Table 2 provides a summary of some field and laboratory work on the removal efficiencies by soil with an emphasis on the biomat zone and the first 90 - $200 \mathrm{~cm}$ of unsaturated media. This list is by no means exhaustive but highlights some key work that has been done in this area.

The hydraulic and purification processes that occur when effluent passes through the biomat and underlying unsaturated zone are closely linked. Within the unsaturated zone, purification processes include sorption, chemical reactions, biotransformation, pathogen die-off and predation, and plant uptake (van Cuyk et al. 2001b). The biomat zone itself is an important component of the purification processes in SAS (Magdoff et al. 1974b; Siegrist 1987). The biomat zone can provide optimal conditions for treatment processes described above due to the increased humidity moisture levels and micro-organism populations present (Siegrist et al. 1991; Baveye et al. 1998). 


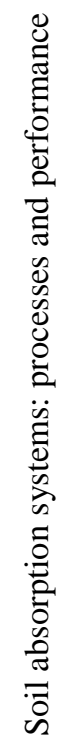

光

$\rightarrow N$ 
4 Role of unsaturated zone in effluent treatment

5 Data collated from Table 2 indicates the importance of the unsaturated depth of media in

6 reducing contaminants in effluent, particularly pathogens. High removal rates of effluent

7 pollutants (eg. pathogens, nutrients, organics and SS) in SAS are correlated with the presence

8 of a well developed biomat zone (Magdoff and Bouma 1974; Kristiansen 1981b,c; Van Cuyk

9 et al. 2001). Soil chemical characteristics, such as cation exchange capacity and organic matter

10 content, are also important factors influencing the degree of effluent treatment in soil

11 (McCardell and Davison 2003; Al-Shiek Khalil et al. 2004; Dawes and Goonetilleke 2004).

12 However, the efficiency of sand media in effluent treatment, particularly the reduction of BOD,

13 SS and pathogens, is also well documented (Crites and Tchobanoglous 1998; van Cuyk et al.

14 2001b; Davison et al. 2002), despite its high hydraulic conductivity and the relatively low

15 physico-chemical activity of sand.

17 The treatment process in a SAS can be likened to the processes which occur in a single-pass

18 sand filter. In a sand filter, effluent is applied intermittently at the top of the sand bed and

19 percolates slowly and evenly throughout the bed. The removal of effluent contaminants occurs

20 mainly in the upper few centimetres of the bed where a biologically active layer is formed

21 (Adin 1998). In a properly functioning SAS, a biomat zone develops at the surface of the soil

22 (bottom of trench) and effluent passes through this biomat and into the unsaturated zone. The

23 presence of a mature biomat will reduce the flow to an extent where unsaturated conditions

24 exist below the biomat, even when there is ponding above the biomat (Fig 5).

Fig. 5. 
28 Unsaturated soil conditions create an environment much like a sand filter system, where the

29 unsaturated zone promotes aerobic degradation of pathogens, prolonged retention time of

30 effluent, and maximum contact with the soil media. Despite this analogy, studies suggest

31 treatment efficiencies in SAS are generally inferior to those reported in sand-based treatment

32 systems (Harrison et al. 2000; USEPA 2002). Much of the data presented in Table 2 has been

33 generated from experiments or field work on sands or sandy soils. This is a clear limitation in

34 the literature as many of the reported failing and / or poorly operating SAS occur in clay soils,

35 rather than in sandy ones.

37 A key difference between an intermittently-dosed sand filter system and a conventional SAS is

38 the inability of a gravity-fed SAS to evenly distribute effluent across the full length of trench

39 bottom. Intermittent pressure dosing of effluent to soil absorption systems has been

40 investigated as a method for improving the aeration status and therefore promoting longevity of

41 a system (McGauhney and Winneberger 1964; Bouma et al. 1974; Uebler 1984; Jenssen and

42 Krogstad 1988). Intermittent dosing can avoid saturated conditions where anaerobic bacteria

43 thrive and accumulate at the infiltration surface (Siegrist et al. 1983; Bancole et al. 2003).

44 Dosing also increases the uniformity of application, thereby reducing the 'creeping failure' that

45 is associated with the localised accumulation of solids and organic materials. Oxygen

46 diffusion can also occur more readily, allowing for the aerobic biodegradation of organic

47 materials and improving the air-filled porosity of the infiltration surface (Bancole et al. 2003;

48 Potts et al. 2004). The mechanisms within the biomat which are responsible for 'recovery' are

49 thought to be associated with decomposition of accumulated organic compounds by oxidative

50 respiration, and drying and contraction of microbial by-products (Bouma et al. 1974). These 
51 processes increase the macropore space within the biomat and allow for greater infiltration.

52 Excessive and localised loading can lead to saturated flow conditions as only a portion of

53 surface area available for effluent dispersal is utilised. In the United States, technologies such

54 as pressure distribution systems are quite commonly incorporated into conventional SAS to

55 improve the distribution of effluent into the trenches / beds (Siegrist et al. 2000). However, in

56 Australia this method for improving system performance has not been so readily adopted -

57 although pressure dosing trenches / beds is referred in the Australian and New Zealand

58 Standard as a method to ensure uniform application (Standards Australia and Standards New

59 Zealand 2000).

60

61 Gas composition in the vadose zone of a SAS is important in the treatment capacity of the 62 system and in its long-term hydraulic functioning (Kristiansen 1981a; Wilhelm et al. 1994a;

63 Potts et al. 2004). There are several investigations (Magdoff et al. 1974a; Magdoff et al.

64 1974b; Gerritse et al. 1995a; Cromer 2001) that demonstrate that aerobic and oxic conditions

65 prevail under trench systems, despite the often saturated nature of the system and the anaerobic

66 character of septic tank effluent. The presence of oxygen, carbon (C) and form of nitrogen (N)

67 determines the composition of the microbial population (aerobic and anaerobic) responsible for

68 effluent treatment. For example, nitrification of ammonium- $\mathrm{N}$ to nitrate will only occur in the

69 presence of oxygen and aerobic bacteria. High rates of complete or near complete nitrification

70 in the unsaturated sub-biomat zone in trenches or soil column experiments have often been

71 reported (Walker et al. 1973a; Pell and Nyberg 1989b; van Cuyk et al. 2001b). 
73 In soil column experiments, Magdoff et al (1974a, 1974b) demonstrated that columns with a

74 developed biomat and perforated sides to allow air exchange, had similar N, C, and phosphorus

75 (P) transformations as columns that had no perforations but had no biomat development.

76 Conversely, columns that had biomat development but no perforations to allow air exchange

77 had lower levels of $\mathrm{N}, \mathrm{P}$ and $\mathrm{C}$ transformation, particularly $\mathrm{N}$ where almost $100 \%$ of the

78 leachate was in the ammonium form (Magdoff et al. 1974b).

$80 \quad$ Organic matter and suspended solids

81 In addition to promoting an aerobic soil environment through the establishment of unsaturated

82 conditions, the biomat acts as a filter in straining and trapping biodegradable organics,

83 measured as BOD and SS. The biomat itself is composed partly of organics and SS originating

84 from septic tank effluent (Bouma 1979; Laak 1986; van Cuyk et al. 2001b). High removal

85 rates of BOD and SS, ranging from $70 \%$ to $95 \%$, have been consistently reported in the

86 literature (Daniel and Bouma 1974; Pell and Nyberg 1989a; van Cuyk et al. 2001b).

88 Pathogens

89 The fate of pathogens (eg. bacteria and viruses) from domestic wastewater has been widely

90 investigated in both field and laboratory environments. The pathways for pathogen export from

91 SAS are surface water run-off from surcharging (hydraulically failing) trenches or groundwater

92 intrusion via saturated flow beneath a trench. Risk of human contact with pathogens from on-

93 site systems generally increases with decreasing temperature, saturated and anaerobic soil

94 conditions (Reneau et al. 1975; Yates and Yates 1988; Beavers and Gardner 1993; Powelson

95 and Mills 2001). Pathogen populations are reduced dramatically by passage through $60 \mathrm{~cm}-$ 
$9690 \mathrm{~cm}$ of unsaturated soil under the biomat zone (Kristiansen 1981c; Powelson et al. 1990;

97 Stevik et al. 1999; Siegrist and Van Cuyk 2001; Pang et al. 2003; van Cuyk et al. 2004).

98 Substantial reductions ( $\leq \log 3-5$ decreases) in bacteria concentrations within $90 \mathrm{~cm}$ depth of 99 unsaturated media have been reported (Rahe et al. 1978; Anderson et al. 1994; Weiskel et al. 100 1996; van Cuyk et al. 2001b; Pang et al. 2003). Population reductions of $>99 \%$ for viruses

101 have been reported in $60 \mathrm{~cm}$ of unsaturated sand (Higgins et al. 1999; Oakley et al. 1999;

102 Siegrist and Van Cuyk 2001). Weiskel et al. (1996) found that although faecal coliforms from

103 SAS contributed the greatest potential load in the Buttermilk Bay catchment, significant 104 subsurface attenuation (4-5 log removal) within the vadose zone $1-2 \mathrm{~m}$ down gradient of the 105 SAS, resulted in an estimated $0.01 \%$ load into the Bay. Many of these studies were done in 106 sandy soils where an unsaturated zone is more likely to occur under a trench due to a greater 107 fraction of air-filled void space due to draining of large pores. However, good pathogen 108 removal rates have been reported in finer-textured soils, for example Oakley et al. (1999) 109 reported 100\% removal of MS2-coliphage in $60 \mathrm{~cm}$ of clay loam.

111 The biomat zone itself plays a greater role in the removal of pathogens from the wastewater 112 stream than it does in the removal of nutrients (van Cuyk and Siegrist 2001). While the 113 anaerobic conditions in the biomat zone are not favourable for inactivation, pathogen removal 114 is facilitated in the biomat zone by straining and adsorption processes. Whelan and Parker 115 (1981) reported a marked reduction of faecal coliforms within approximately 30cm below the 116 biomat zone of a SAS located in a in a sandy soil. 
118 Alhajjar et al. (1988) reported that filtering in the biomat zone effectively removed bacteria,

119 but not the much smaller poliovirus; although the biomat zone appeared to at least retard the

120 passage of poliovirus into the ground water. Both Bouma et al. (1972) and Van Cuyk et al.

121 (2001) observed high densities of coliform bacteria in the biomat zone (approximately 15-20

122 mm thick). Lysimeter experiments have demonstrated an association between the stage of

123 biomat development and pathogen removal percentage, where a proportional increase in

124 removal rates occurred as the biomat matures (van Cuyk et al. 2001b). However, it is unclear

125 whether this relationship was tested for statistical significance. In van Cuyk et al.’s study, viral

126 die-off through the unsaturated zone was calculated by a one-dimensional model where

127 microbial die-off is described as:

128

$$
C_{t}=C_{o} \exp (-k t)
$$

130 where $\mathrm{C}_{t}$ is the concentration of viruses at time, $t$ (days), $\mathrm{C}_{o}$ is the initial concentration of

131 viruses (pfu/mL) and $k$ is the first-order rate co-efficient for net die-off rate of viruses.

133 The retention time in the vadose zone was described as:

$$
t=\frac{\text { SoilDepthxEffectivePorosityxEIS }}{\text { EffluentApplicationRate }}
$$

137 where EIS is the effective infiltration surface which is 1 for a mature trench and 0 for a new

138 trench (van Cuyk et al. 2001b). Van Cuyk et al. (2001) used Equations 5 and 6 to investigate

139 whether the type of infiltrative surface (e.g. gravel versus gravel-free sand lysimeters) was

140 important in the treatment efficiency. The authors found comparable treatment efficiencies 
141 between the two surfaces, and suggested that hydraulic retention time and proportion of surface

142 utilised was more important than the type of surface. This paper drew a credible link between

143 hydraulic processes and treatment efficiency, and illustrated the importance of the first few

144 centimetres, including the biomat zone, in SAS performance.

145

146 Pathogen removal in SAS is well-studied and generally understood in terms of the need for an

147 unsaturated zone for effective treatment of effluent. Without this vadose zone, the chances of

148 pathogens contaminating groundwaters are much higher. Pathogen pollution into surface

149 waters (via run-off) in non-sewered areas has also been explored (Geary 1992; Heisig 2000;

150 Graves et al. 2002; Ahmed et al. 2005). It can be difficult to unambiguously determine the

151 contribution from on-site systems to pathogen pollution due to difficulties in identifying other

152 sources of faecal pollution (e.g. birds and animals). However, there is an increasing number of

153 water quality studies using methods to differentiate between human and non-human sources of

154 faecal pollution, as discussed in more detail later.

$156 \quad$ Nitrogen

157 Several factors influence how effectively $\mathrm{N}$ is assimilated in the soil. The redox status, soil

158 microbial composition and labile C source are the key factors which determine the degree of 159 total $\mathrm{N}$ removal in a SAS (Wilhelm et al. 1994a; EPRI 2000). The main form of $\mathrm{N}$ in septic 160 tank effluent is ammonium (Whelan and Titamnis 1982) and this commonly undergoes rapid 161 nitrification once the effluent leaches into the unsaturated, aerobic zone underlying the biomat 162 zone (Aravena et al. 1993; Wilhelm et al. 1994b; Aravena and Robertson 1998). Removal of 163 nitrate, the product of nitrification, is not efficient in the aerobic, low $\mathrm{C}$ soil conditions of the 
164 unsaturated zone as these conditions inhibit denitrification and subsequent gaseous loss of $\mathrm{N}$.

165 Whelan and Barrow (1984a) found that nitrification was inhibited by the anaerobic state of the

166 biomat layer, but once the effluent passed through the biomat, nitrification was almost

167 complete within half a metre. Other researchers have described similar results with virtually

168 complete nitrification occurring within a few centimetres of the bottom of the biomat zone

169 (Walker et al. 1973b; Kristiansen 1981b; Cogger et al. 1988; Pell and Nyberg 1989b; Gerritse

170 et al. 1995b). Nitrogen can also be physically removed from the effluent via filtration through

171 the biomat as observed by Magdoff and Bouma (1974). They found high concentrations of

172 organic $\mathrm{N}$ at, and just below, the infiltrative surface layer of clogged soil columns where a

173 biomat was present compared with columns where there was no biomat present (Magdoff and

174 Bouma 1974). Under anaerobic conditions (i. e. no opportunity for conversion to nitrate), 175 ammonium adsorption can occur (Harrison et al. 2000) particularly for soils with a high cation 176 exchange capacity e.g. montmorillonitic soils (McCardell and Davison 2003).

178 Although removal of total $\mathrm{N}$ in SAS is generally not efficient, due to the absence of a 179 significant denitrification phase, there is some evidence to suggest $\mathrm{N}$ removal by SAS can 180 occur. Dawes and Goonetilleke (2003) reported that the greatest improvement in water quality 181 occurred within $1 \mathrm{~m}$ of absorption trenches (sample size 16 SAS) with negligible further 182 removal between 1-3m from trench. Data was not given on the removal rates between the 183 trench and the piezometers located $1 \mathrm{~m}$ from the trench, though this data would have been 184 useful. Cromer (2001) reported markedly reduced nitrate concentrations within $10 \mathrm{~m}$ to $20 \mathrm{~m}$ 185 from the trench located in a sandy soil in Hobart, Tasmania. Unfortunately only one SAS was 186 investigated in this study, thus limiting the comparison of these results with similar coastal 
187 environments. Gerritse et al. (1995b) using a mass balance of inorganic N and bromide,

188 reported $\approx 80 \%$ of $\mathrm{N}$ was lost within $10 \mathrm{~m}$ of travel in sandy soil in Peth, Western Australia.

189 They concluded that $\mathrm{N}$ additions to catchment waterways were originating to a much greater

190 extent from agricultural areas compared to non-sewered areas (Gerritse et al., 1995b).

192 In general though, loss of $\mathrm{N}$ from SAS is usually poor and elevated nitrate concentrations in 193 groundwater associated with SAS have been well-documented (EPRI 2000). Tracer 194 experiments have revealed that nitrate can travel in aquifers underlying SAS in relatively well195 defined, narrow plumes which have been recorded to be up to $130 \mathrm{~m}$ in length (Robertson et al. 196 1991) but may extend up to 200 m (Valiela et al. 1997).

\section{Denitrification}

199 In the absence of oxygen, nitrate can be lost from the system by denitrification, providing a 200 supply of labile C is available. Optimal conditions for denitrification are generally limited to 201 small anaerobic pockets in the vadose zone or the biomat itself, therefore $\mathrm{N}$ removal is 202 generally low in SAS (Reneau et al. 1975; Wilhelm et al. 1994a). However, with their source 203 of labile C and often anaerobic soil conditions, riparian zones, can help to reduce nitrate 204 concentrations in (shallow $\leq 2 \mathrm{~m}$ ) groundwater that intercepts this zone (Robertson et al. 1991; 205 Hill 1996; Anderson 1999; Gold et al. 1999).

207 Denitrification in riparian zones has been reported to be both spatially and temporally variable 208 (Gold et al. 1999). Robertson et al. (1997) studied plumes from SAS in sandy soils and found 209 that over time, SAS-derived nitrate concentrations in receiving waters were much lower than 
210 expected, and concluded that denitrification in the riparian zone was a key removal mechanism

211 for nitrate. Geary (2004) demonstrated the importance of downstream riparian zones in his

212 reporting of substantial nitrate losses between an absorption trench and an adjacent surface

213 water body. Groundwater nitrate concentrations decreased from a mean of $75 \mathrm{mg} / \mathrm{L}$ to a mean

214 of $2.8 \mathrm{mg} / \mathrm{L}$ over a distance of approximately $3 \mathrm{~m}$ (Geary 2004). A riparian strip was situated

215 between the two monitoring points, and Geary (2004) suggested that nitrate loss was from

216 plant uptake, denitrification and possibly dilution from converging groundwater flows.

217 Chemical denitrification can also occur in certain soils, for example the oxidation of pyrite,

218 using nitrate as an electron acceptor, will produce nitrogen gas (Postma et al. 1991).

220 Phosphorus

221 The main form of $\mathrm{P}$ in septic tank effluent is orthophosphate. The geochemical mechanisms 222 influencing the availability of $\mathrm{P}$ in and below SAS are adsorption/desorption, 223 precipitation/dissolution and biological immobilisation (EPRI 2000). Most studies indicate 224 that $\mathrm{P}$ removal in SAS is generally effective (Brouwer and Bugeja 1983; Gerritse 1993; 225 Wilhelm et al. 1996; Robertson and Harman 1999). In general, soils (including many sandy 226 soils) have the capacity to retain P (Jones and Lee 1979; Weiskel and Howes 1992).

228 While the role of the biomat on $\mathrm{P}$ removal is poorly understood, clearly some retention of $\mathrm{P}$ 229 would occur during the development phase of the biomat zone. Phosphate removal is certainly 230 indirectly influenced by the biomat, if not directly. Sub-biomat soil conditions such as redox 231 and $\mathrm{pH}$, which are important in P retention processes, are influenced substantially by the extent 232 of biomat development. Magdoff et al. (1974b) found greater P removal in soil columns with 
233 well developed biomats compared to columns with poorly developed or absent biomats.

234 Changes to $\mathrm{pH}$ conditions in and just below the biomat were suggested as one factor

235 contributing to this difference.

236

237 Phosphate is more strongly retained by the soil matrix under conditions of high $\mathrm{pH}$ and 238 oxidation status (Ponnamperuma 1972), conditions which are more likely to prevail in an 239 aerobic, unsaturated environment that is promoted by the presence of an overlying biomat 240 zone. Localised P enrichment can lead to slow release of P into groundwaters over the long241 term, though has only been reported for sandy soils (Whelan and Barrow 1984b; Gerritse et al.

242 1995a). Calcareous sands however, have been reported to have a good ability to retain P via

243 rapid sorption then slow precipitation of phosphate with calcium to form amorphous crystalline

244 minerals (Wilhelm et al. 1994a). Soils containing high sesquioxide (iron and aluminium

245 hydrous oxides) fractions can strongly adsorb P (Menzies et al. 1999; Redding et al. 2002).

246 Precipitation of calcium and iron phosphates have also been observed below SAS (Whelan and

247 Barrow 1984b). Saturation of soils, or soils exposed to alternate wetting and drying cycles, of

248 which both scenarios may occur in SAS, will also influence P retention. Ptacek (1998) and

249 Zanini et al. (1998) describe the influence of suboxic and oxic regions on $\mathrm{P}$ within the subsoil

250 and aquifer zones below SAS. For example, Ptacek (1998) describes the elevated presence of

251 vivianite, an amorphous ferric phosphate, which has been formed following dissolution and

252 subsequent precipitation in the more reduced lower zones of the aquifer.

253

254 The influence of micro-scale characteristics in the biomat, vadose and aquifer zone on nutrient 255 assimilation is really only superficially understood in terms of the long term treatment capacity 
256 of SAS. Gold and Sims (2000) describe several areas of nutrient dynamics in SAS which

257 require further research, particularly in the context of developing a risk-based model for SAS

258 design and siting.

259

260 Environmental and human health impacts associated with on-site systems

261 Both hydraulic and treatment failures can occur from a poorly operating SAS. Hydraulic

262 failure (surcharging) occurs when the infiltration rates through the biomat are exceeded by the

263 loading rate of effluent into the trench, resulting in effluent discharge onto the soil surface.

264 Field studies have identified this as a relatively common occurrence for older and / or poorly

265 designed SAS (Brouwer et al. 1979; Geary 1994; Dawes and Goonetilleke 2001). Treatment

266 failure is less obvious and is linked closely with the soil biogeochemical processes governing

267 the hydraulic behaviour in the soil system (Siegrist and Van Cuyk 2001). A shallow water table

268 and / or saturated subsoil can result in inadequately treated effluent entering the groundwater.

269 The shortened hydraulic retention time and reduced aerobic conditions that occur in these

270 circumstances preclude adequate treatment of effluent prior to contact with groundwater. Both

271 forms of failure may ultimately result in effluent pollutants (nutrients and pathogens) being

272 exported from the application area and entering surface and / or groundwaters (see selected

273 studies in Table 3).

274 
है

$\stackrel{\circ}{N}$ 
277 The pollutants of key environmental concern are $\mathrm{N}$ and P. Nutrient enrichment of a freshwater

278 body can lead to accelerated eutrophication. Land use practices such as agriculture and

279 horticulture, are well studied sources of contaminant loads into catchments (Kookana et al.

280 1998). However, non-sewered areas have also been shown to contribute to catchment nutrient

281 loads (Valiela and Costa 1988; Weiskel et al. 1996).

282

283 Clear hydraulic links have been made between on-site wastewater dispersal practices and

284 nutrient contamination of ground and surface waters (Table 3) with the use of tracers such as

285 bromide (eg. Robertson et al. 1991), chloride (e.g. Stewart and Reneau 1988), ${ }^{15} \mathrm{~N}$ stable

286 isotopes (eg. Chen and Harkin 1998), sterol biomarkers (eg. Leeming et al. 1996), and viral

287 tracers (eg. Paul et al. 1995). All of these studies have found some causal link between

288 elevated effluent-derived pollutant in groundwaters and OWTS, specifically septic systems. It

289 is the degree and impact of contribution to ground and surface water contamination that

290 remains ambiguous in these studies. The extent of contamination is extremely variable and can

291 be a function of soil type and unsaturated soil depth, existing quality of water body, OWTS

292 density and distance to receptor, groundwater flow velocity, climate and seasonal factors, and

293 age and design of system.

294

295 Human health impacts

296 Concern over microbiological contamination from SAS, particularly in groundwater, has been

297 rising over the years, but as Van Cuyk and Siegrist (2001) suggest, this appears to be based on

298 the widespread distribution of on-site wastewater systems, rather than documented evidence. 
299 Where there have been reports of SAS-related waterborne disease outbreaks, these have 300 usually been localised and associated with a single poorly performing system (Yates and Yates

301 1988; Cliver 2000; Bopp et al. 2003) (Table 3). Cumulative impacts and catchment-wide

302 pathogen loads in non-sewered areas have not been adequately investigated and / or reported.

303 Obviously, there are economic and logistical difficulties in quantifying the origins of a specific

304 diffuse-source pollutant, although catchment water quality models have proved a useful tool in 305 this regard (Yates and Yates 1988; Tong and Chen 2002; Weintraub et al. 2002; Whitehead et 306 al. 2003).

308 Several studies have considered cesspools, leaching pools and injection wells as sources of

309 pollution (Table 3) as well as the conventional SAS (Vaughn et al. 1983; Chen 1988; Dillon et

310 al. 2000). Unlike SAS, cesspools and injection wells are not specifically designed to interact

311 with the soil as part of the key treatment process and they are therefore more likely to provide a

312 substandard level of treatment (USEPA 2002). Despite this, they are commonly grouped in

313 with SAS statistics on failure or poor performance of 'septic systems' (Craun 1985; Dillon et 314 al. 1999; USEPA 2002).

315 The number of drinking water-associated disease outbreaks in the United States decreased from 31639 during 1999-2000 to 31 during 2001-2002 (Blackburn et al. 2004). These 31 outbreaks 317 caused illness among an estimated 1,020 persons, with 52 people (5.5\%) becoming ill from 318 drinking groundwater in 'individual' homes which were presumably non-sewered (Blackburn 319 et al. 2004). Assuming these 52 cases were in non-sewered areas, this represents about $7 \times 10^{-}$ $3205 \%$ of the non-sewered population in the United States (on the basis that $23 \%$ of the population 321 lives in non-sewered areas (USEPA 2002)). Outbreaks associated with private wells remained 
322 relatively stable, although there was an increase in reporting of outbreaks involving private,

323 treated wells during 2001-2002 (Blackburn et al. 2004).

324 The contaminant that is repeatedly found in elevated concentrations in groundwaters down

325 gradient from SAS is nitrate (Robertson et al. 1991; Harman et al. 1996; Robertson et al. 2000;

326 Steffy and Kilham 2004). Despite this, it is interesting to note that very few reports of nitrate

327 toxicity associated with SAS are present in the literature. L'hirondel and L'hirondel (2002)

328 critically examined the evidence for well-water induced methaemoglobinaemia. They

329 concluded that there was a poor correlation between high concentrations of nitrates in well-

330 water and infant methaemoglobinaemia (blue-baby syndrome), with the cases of infant

331 methaemoglobinaemia almost completely absent in the US since 1960 (L'hirondel and

332 L'hirondel 2002). Elevated nitrates in well-water have been linked to privies and cesspools but

333 there is scant mention of the conventional SAS being linked to well-water

334 methaemoglobinaemia. Obviously there is much evidence reporting elevated groundwater

335 nitrate concentrations from SAS, however the assumption that these elevated nitrate levels

336 from SAS are a human health problem should not be automatic and there appears to be little

337 recent scientific evidence to support this assumption.

\section{Australian studies}

340 In 1997 over 400 people contracted Hepatitis A from eating suspected sewage-contaminated

341 oysters from Wallis Lake (Ryan v Great Lakes Council 1999), triggering the formation of the

342 SepticSafe programme by NSW Department of Local Government. There have been several

343 studies in Australia investigating the contamination of surface and groundwaters from septic

344 systems before and after the Wallis Lake incident (Geary 1994; Hoxley and Dudding 1994; 
345 Jelliffe 1998; Whitehead and Geary 2000). A common problem with many investigations into

346 SAS impacts in Australia are the poor datasets and / or evidence of clear links to SAS as the 347 source of contamination.

349 A study of two rural towns in Victoria reported variable concentrations of nitrate and faecal

350 coliforms in shallow groundwater below areas of high SAS densities (Hoxley and Dudding

351 1994). However, most of the data which was discussed was not presented in the paper. The

352 authors concluded that "other towns or cities that have septic tanks in densities similar.. are

353 most likely causing nitrate and bacteriological contamination of the local groundwater...”

354 (Hoxley and Dudding, 1994). This conclusion is highly generalised and very likely to be

355 inaccurate given the wealth of literature that demonstrates treatment in SAS is determined by a

356 number of factors including site and soil conditions, system type, loading rates and depth to 357 groundwater (length of vadose zone).

359 Sampling and monitoring of surface water, downstream of non-sewered communities on 360 Scotland Island, NSW, showed high concentrations of faecal coliform and enterococci 361 (Martens and Geary 1999). These results, together with sampling and testing of effluent in 362 absorption trenches, led the authors to conclude that the transportation of poorly treated septic 363 tank effluent into surface waters resulted in excessively high bacterial concentrations (Martens 364 and Geary 1999). However, the report did not clearly state the number of water quality 365 samples taken, or if other land use practices and sources of bacterial pollution were considered. 366 Additionally, sampling methods for the drainfield water quality samples were unclear. The 367 results provided appear to indicate that the effluent is of primary treated quality, which 
368 suggests that the samples were taken (prematurely) in the saturated zone within the trench

369 itself, rather than the underlying vadose zone where treatment predominantly occurs.

371 In southeast Queensland the majority of septic systems use separate greywater and blackwater

372 treatment and dispersal (Beal et al. 2005). Beal et al. (2005) identified the key management

373 issues in the region as the frequency of greywater failure and inappropriate greywater

374 discharge, and suggested that the common practice of discharging effluent into streams, gutters

375 and drains (Jelliffe et al. 1995; Beal et al. 2005) may be making the greatest contribution to

376 OWTS-related water quality impacts.

378 To date, only a few Australian investigations have been able to demonstrate conclusive 379 evidence of pollution of groundwater by on-site systems. The contribution of on-site systems 380 to poor surface water quality is even more ambiguous. This can, in part, be attributed to the 381 difficulties associated with quantifying diffuse pollution sources. It can also be difficult to 382 clearly determine the contribution from on-site systems to pathogen pollution due to 383 difficulties in separating human-sources from other sources of faecal pollution (e.g. birds and 384 animals). However, there is an increasing number of studies using methods to differentiate 385 between human and non-human sources of faecal pollution. Recent work using 'biomarkers' as 386 a method of distinguishing human faecal contamination from that of other animals is gaining 387 impetus as a useful tool for assessing water quality impacts to catchment water quality, 388 particularly from diffuse sources such as on-site wastewater systems and agricultural land use 389 (Apte and Bately 1992; Leeming 1998; Geary and Davies 2004). Data obtained from such 
390 studies will provide more certainty of the role on-site systems play in catchment water quality

391 degradation.

392

393 In areas where shellfish such as oysters are farmed for human consumption, the risks of human

394 health impacts from faecal contamination are increased. Oysters, being filter feeders, are

395 particularly vulnerable to bioaccumulation of contaminants due to their highly efficient

396 filtering capacity compared with humans, for example Pacific oysters can filter up to 50L of

397 water per day (Bayne et al. 1999). Geary and Davies (2004) used bacterial source tracking in

398 the shellfish farming region of Port Stephens, NSW, to determine the source of faecal

399 streptococci isolates. They reported that although there was no one source that was statistically

400 significant, SAS were considered one human source of faecal streptococci.

401

402 Ahmed et al. (2005) used biochemical fingerprinting to identify unique E. coli and enterococci

403 phenotypes in a south-east Queensland waterway. A total of 151 unique biochemical

404 phenotypes, that were identified from 48 septic tanks, were found in Eudlo Creek downstream

405 of a non-sewered area. Of these septic tanks, 23 had absorption trenches that were classified as

406 'soggy' (surface surcharging) and 32 required desludging during the study (Ahmed et al.

407 2005). Unfortunately, the testing is not quantitative so it is impossible to ascertain whether

408 these phenotypes were substantial contributors to the total faecal contamination load in the 409 creek.

411 The actual impacts (e.g. disease, eutrophication, nitrate toxicity) from on-site effluent-polluted 412 waterways are poorly documented. For example, there are few reported cases of outbreaks of 
413 endemic illness (Table 3) in areas of high system density and permeable soils; though this

414 would be expected if serious groundwater contamination was present; as was purported to be

415 the case by Hoxley and Dudding (1994). It is acknowledged however, that reporting depends

416 on whether the illness is notifiable or reportable. Absence of evidence is obviously not

417 evidence of absence, and the need for well-considered, long-term water quality monitoring in

418 non-sewered areas is essential to build up an accurate picture of the location, number, and

419 degree of failing on-site systems. This is becoming particularly pressing in areas of high

420 density non-sewered development located near sensitive water receptors and / or on shallow

421 aquifers. Water quality monitoring programmes which generate useful data are difficult to

422 undertake. Event-based monitoring, in addition to baseflow monitoring, is essential as

423 significant surface export of effluent contaminants is only likely to occur during storm events.

424 As discussed, human-sourced faecal pollutants need to be separated from other animals, and

425 SAS-derived nitrate also needs to be discriminated from that arising from other land uses. In

426 this respect, using $\delta \mathrm{N}^{15}$ may be applicable (Steffy and Kilham 2004).

427

\section{Density of on-site systems}

429 A key factor in sustainable OWTS management is providing sufficient lot area for pollution

430 reduction. As the density of on-site systems increases, there is greater potential for adverse

431 impacts such as cumulative water quality contamination (nitrates) and groundwater mounding

432 (Siegrist et al. 2000). Allotment density is determined largely by the horizontal (and vertical)

433 setback distances required in each lot in order for sufficient assimilation of effluent pollutants

434 to occur. Research generally suggests that as OWTS density increases, pollutant loads (e.g 435 nitrates and pathogens) in ground waters have also increased (Perkins 1984; Yates 1985; 
436 Tuthill et al. 1998; Lipp et al. 2001). Hence, on-site system density is becoming a critical issue

437 in rapidly developing non-sewered areas, and there is a need to determine sustainable lot

438 densities, although this is an inherently difficult task to undertake. A major problem in

439 determining minimum setback distances from on-site systems is estimating the proportion of

440 off-site export of contaminants due to pollutant concentration reduction and reinfiltration,

441 which will vary from site to site.

443 Despite the difficulties there have been some attempts to quantify minimum lot densities 444 (Perkins 1984; Yates 1985; Geary and Gardner 1998; Jelliffe 1999). A density of greater than

44515 systems $/ \mathrm{km}^{2}$ is quoted as being unsustainable, although as Whitehead et al. (Whitehead et 446 al. 2001) point out, this is based on very limited data. Jelliffe (1998) suggested that setback 447 distances to contain surface exports should vary with soil type and the target receiving water 448 quality objectives, and proposed a relatively simple biophysical model to calculate sufficient 449 nutrient assimilation area. A summary of some minimum lot sizes and densities recommended 450 in the literature is provided in Table 4.

\section{Table 4}

453

454 There is considerable variation between what is considered a sustainable lot size (Table 4). 455 This is partly due to the variety of factors determining the assimilative capability of a site, 456 partly due to the environmental sensitivity of the area, and partly a result of inadequate 457 knowledge of treatment processes / removal efficiencies of on-site systems. 


\section{Areas of further research}

460 The 'National Research Needs' Conference held in the United States in 2000 aimed to identify 461 and discuss essential research areas for on-site wastewater management (EPRI 2000). Many of 462 the identified research needs also apply in Australia, including the development of sound risk463 based decision making tools, greater understanding of the interactions between hydraulic and 464 treatment mechanisms in SAS, pathogen pathways and removal processes, and the 465 minimisation of nitrate export to groundwater. Some key research areas which can be 466 identified from this literature review are summarised in Table 5.

\section{Table 5.}

470 Many of the studies presented in Tables 2 and 3 were undertaken in sandy media, with medium 471 to low clay content. Obviously soils are highly variable and more research across a range of 472 soils types would benefit our understanding of hydrology and treatment processes occurring, 473 not only in SAS, but also on soils being irrigated with secondary effluent from alternative on474 site systems.

475

476 Greater knowledge of the biomat zone development, and its interaction with oxygen 477 availability and subsequent $\mathrm{N}$ and pathogen transformations, would be a useful advance in 478 predicting the long-term performance of SAS. Research into improvements in nitrate reduction 479 in the sub-biomat zone, is essential for the sustainable future of SAS.

481 Identifying and evaluating the potential risks to receiving water bodies from on-site systems is 482 becoming an increasingly popular management approach (Jones et al. 2000; Whitehead et al. 
483 2003; Day 2004). Risk assessment concepts have been implicitly included in regulatory

484 guidelines for many years; for example, the imposition of setback distance criteria of an OWTS

485 to a boundary or sensitive receptor. However, setback distances are site-specific and a risk-

486 based management approach could help to determine suitable setback distances and sustainable

487 OWTS densities at a site and catchment scale. A good risk assessment would also consider

488 cumulative impacts from on-site systems; something which has received little attention in the

489 literature, or from regulators. Research into risk assessment models is being undertaken to

490 investigate their viability and applicability as a tool in onsite system risk assessment. These

491 include the On-site Sewage Assessment Risk Assessment System (OSRAS) (Whitehead et al.

492 2003), the Development Assessment Module (DAM) (McGuinness and Martens 2003) and a

493 Quantitative Microbial Risk Assessment (Charles and Ashbolt 2004).

\section{Summary}

496 The mechanisms governing purification and hydraulic performance of a SAS are complex and

497 have been shown to be highly influenced by the biomat zone which develops on the soil

498 infiltrative surface within a SAS. The physical, chemical and biological processes that occur in

499 the biomat zone and underlying unsaturated zone are complex and dynamically interactive.

500 Hydraulic and purification processes do not occur separately from each other but interact in a

501 complex, yet potentially predictable way. Equations defining the theoretical movement of

502 effluent through barriers and unsaturated soil zones have been described (eg. Bouma 1975),

503 and more recently, attempts have been made to predict soil clogging development (Siegrist and

504 Boyle 1987; Weintraub et al. 2002) and to model the clogging zone impact to flow (Huntzinger

505 Beach and McCray 2003; Beal et al. 2004b). 
507 Laboratory studies involving soil columns and lysimeters, designed with an increasing degree

508 of complexity, have yielded many valuable insights and illuminated our understanding of soil-

509 effluent relationships in various media. Field investigations have, in many cases, validated the

510 results and theories from laboratory studies. Field surveys have identified commonalities in

511 hydraulic failure (poor design, low permeable soil, severe clogging) and purification failure

512 (shallow water table, highly permeable soil, shallow depth of unsaturated zone) between SAS.

513 Although there has been considerable research in the area of on-site wastewater management

514 and soil-based treatment systems, some key processes remain unclear.

516 Key treatment processes, occurring in the unsaturated zone beneath a SAS are oxidation, 517 adsorption, pathogen die-off, and ion exchange. Studies of effluent plumes under SAS, and 518 water quality monitoring in non-sewered areas, suggest that on-site systems are contributing to

519 poor water quality. Nitrate and faecal pollution are the two major effluent contaminants.

520 Groundwater nitrate concentrations have been widely reported in non-sewered areas, 521 particularly in high allotment densities on permeable soils and / or shallow water tables. The 522 contribution of on-site systems to catchment pollutant loads and cumulative water quality 523 effects is less clear. In this respect, targeted water quality monitoring, identified from a risk 524 assessment process, is recommended to improve our knowledge of pollution potential of on525 site systems.

527 In terms of future research, a greater understanding the interactions between hydraulic and 528 treatment mechanisms, and the biomat and sub-biomat zone gas composition including its role 
529 in effluent treatment is needed. Improved $\mathrm{N}$ removal in SAS remains a priority. Further work 530 on the role of the riparian zone in the reduction of nitrates and the design of systems that 531 incorporate C enriched layers (e.g. Bedessem et al. 2005) is necessary. The critical lot density 532 in non-sewered areas is not well understood and consequently setback distances are often 533 unjustified and conservative. Improving our knowledge of micro-scale and site scale processes 534 will lead to a greater understanding of catchment scale impacts from on-site systems.

535

536

537 


\section{References}

Adin A (1998) Physicochemical mechanisms in treatment processes for water reuse. In 'Wastewater reclamation and reuse'. (Ed. T Asano). (Technomic Publishing Co. Inc.: USA)

Ahmed W, Neller R, Katouli M (2005) Evidence of septic system failure determined by a bacterial biochemical fingerprinting method. Journal of Applied Microbiology 98, 910-920.

Alhajjar BJ, Stramer SL, Cliver DO, Harkin JM (1988) Transport modelling of biological tracers from septic systems. Water Research 22, 907-915.

Allison LE (1947) Effect of microorganisms on permeability of soil under prolonged submergence. Soil Science 63, 439-450.

Al-Shiek Khalil WR, Goonetilleke A, Rigby PA (2004) Use of undisturbed soil columns to evaluate soil capability to renovate on-site sewage treatment system effluent. In 'Tenth National Symposium on Individual and Small Community Sewage Systems'. March 21-24, Sacramento, California pp. 201-209. (ASAE, St Joseph, USA)

Anderson DL (1999) Natural denitrification in shallow groundwater systems. In 'Proceedings 10th Northwest Onsite Wastewater Shortcourse, Univ. Washington, Seattle WA' pp. 201-210

Anderson DL, Otis RJ, McNellie JJ, Apfel RA (1994) In-situ lysimeter investigation of pollutant attenuation in the vadose zone of a fine sand. In 'Proceedings of the Seventh National Symposium on Individual and Small Community Sewage Systems'. Atlanta, Georgia pp. 209-218. (ASAE; St Joseph; USA)

Apte SC, Bately GE (1992) Rapid detection of sewage contamination in natural waters. Chemistry in Australia 59, 397-399.

Aravena R, Evans ML, Cherry JA (1993) Stable isotopes of oxygen and nitrogen in source identification of nitrate from septic systems. Ground Water 31, 180-186.

Aravena R, Robertson WD (1998) Use of multiple isotope tracers to evaluate denitrification in ground water: Study of nitrate from a large-flux septic system plume. Ground Water 36, 975-982.

Bancole A, Brissaud F, Gnagne T (2003) Oxidation processes and clogging in intermittent unsaturated infiltration. Water Science and Technology 48, 139-146.

Baveye P, Vandevivere P, Hoyle BL, DeLeo PC, de Lozada DS (1998) Environmental impact and mechanisms of the biological clogging of saturated soils and aquifer materials. Critical Reviews in Environmental Science and Technology 28, 123-191.

Bayne BL, Hedgecock D, McGoldrick D, Rees R (1999) Feeding behaviour and metabolic efficiency contribute to growth heterosis in Pacific oysters [Crassostrea gigas (Thunberg)]. Journal of Experimental Marine Biology and Ecology 233, 115-130.

Beal CD, Gardner EA, Christiansen C, Beavers P (2005) A review of on-site wastewater management practices in south-east Queensland. Water (Australia) 32 (4), 69-72.

Beal CD, Gardner EA, Menzies NW, Rassam DW, Vieritz AM (2004b) Prediction of steady-state flux through variably saturated zones within a septic absorption trench. In 'Proceedings of the International Soil Science Conference, Dec. 2004, Sydney, Australia' 
Beal CD, Gardner EA, Vieritz AM, Menzies NW (2004a) The role of the biomat in the sustainable performance of soil absorption systems in Australia: A review. In 'Proceedings of the Tenth National Symposium on Individual and Small Community Sewage Systems'. Sacramento, CA pp. 241-248. (ASAE, St Joseph, USA)

Beavers PD, Gardner EA (1993) Prediction of virus transport through soils. In '15th AWWA Federal Convention, Gold Coast QLD,' pp. 530-535. (AWWA Canberra ACT)

Bedessem ME, Edgar TV, Roll R (2005) Nitrogen removal in laboratory model leachfields with organic rich layers. Journal of Environmental Quality 34, 936-942.

Blackburn MD, Craun G, Yoder JS, Hill V, Calderon R, Chen N, Lee S, Levy D, Beach M (2004) 'Surveillance for waterborne-disease outbreaks - United States, 2001 - 2002.' In: Surveillance Summaries, October 22, 2004. MMWR 2004; 53 (No. SS-8):23-45.

Bopp DJ, Sauders BD, et al. (2003) Detection, isolation and molecular subtyping of Escherichia coli O157:H7 and Campylobacter jejuni associated with a large waterborne outbreak. Journal of Clinical Microbiology 41, 174180.

Borchardt MA, Chyou P, De Vries E, O, Belongia EA (2003) Septic system density and infectious diarrhea in a defined population of children. Environmental Health Perspectives 111, 742-747.

Bouma J (1975) Unsaturated flow during soil treatment of septic tank effluent. Journal of Environmental Engineering, 967-981.

Bouma J (1979) Subsurface applications of sewage effluent septic tanks, soil factors, hydrology, pathogens. Agronomy Advances Series Monograph, American Society of Agronomists, 665-703.

Bouma J, Converse JC, Magdoff FR (1974) Dosing and resting to improve soil absorption beds. Transactions of the ASAE 17, 295-298.

Bouma J, Ziebell WA, Walker PG, Olcott PG, McCoy EL, Hole FD (1972) 'Soil absorption of septic tank effluent: a field study of some major soils in Wisconsin.' (University of Wisconsin Extension Circular no. 20, Soil Survey Division, Wisconsin. 235 p)

Brandes M (1978) Characteristics of effluents from gray and black water septic tanks. Journal of Water Pollution Control Federation 50, 2547-2559.

Brouwer J, Bugeja RM (1983) 'Land capability for septic tank effluent absorption fields -part A: project report.' Australian Water Resources Council Research Project No 79/118, Canberra.

Brouwer J, Willatt ST, van der Graaff R (1979) The hydrology of on-site septic tank effluent disposal on a yellow duplex soil. In 'Hydrology and Water Resources Symposium, 10-12 Sept 1979, Perth'. (IEAust, ACT)

Carroll SP, Goonetilleke A, Hargreaves M (2004) Assessment of environmental and public health risk of on-site wastewater treatment systems. In 'Proceedings of the Tenth National Symposium on Individual and Small Community Sewage Systems'. Sacramento, CA pp. 368-376. (ASAE, St Joseph, USA)

Charles K, Ashbolt N (2004) Quantitative Microbial Risk Assessment: a catchment management tool to delineate setback distances for septic systems. In 'Water and Environmental Management Series (Young Researchers Conference 2004)'. (Eds P Lens and R Stuetz). (IWA: Wageningen, The Netherlands)

Charles KJ, Ashbolt NJ, Roser DJ, McGuinness R, Deere DA (2004) Effluent quality from 200 on-site sewage systems: Design values for guidelines. In '6th Specialist Conference on Small Water \& Wastewater Systems and 1st International Conference on Onsite Wastewater Treatment \& Recycling, Fremantle, WA, Australia, International Water Association (IWA).' 
647 Chen C, Harkin JM (1998) Transformations and transport of ${ }^{15} \mathrm{~N}$-based fixed nitrogen from septic tanks in soil 648 absorption systems and underlying aquifers. In 'Proceedings of the Eighth National Symposium on Individual and 649 Small Community Sewage Systems'. Orlando, Florida pp. 293-305. (ASAE; St Joseph; USA)

Chen M (1988) Pollution of groundwater by nutrients and fecal coliforms from lakeshore septic tank systems. Water Air and Soil Pollution 73, 407-417.

Cliver DO (2000) Research needs in decentralized wastewater treatment and management: Fate and transport of pathogens. National Research Needs Conference Proceedings: Risk Based Decision Making for Onsite Wastewater Treatment. EPRI Palo Alto, CA, U.S. Environmental Protection Agency and National Decentralized Water Resources Capacity Development Project: 20011101446 p. 31

Cogger CG (1988) On-site septic systems: The risk of groundwater contamination. Journal of Environmental Health 51, 12-16.

Cogger CG, Hajjar LM, Moe CL, Sobsey MD (1988) Septic system performance on a coastal barrier island. Journal of Environmental Quality 17, 401-407.

Converse JC, Tyler EJ, Sievers DM (1998) Soil treatment of aerobically treated domestic waste water with emphasis on modified mounds. In 'On site wastewater treatment. Proceedings of the Eighth National Symposium on Individual and Small Community Sewage Systems, Orlando, Florida, USA,'. ((ASAE); St Joseph; USA)

Craun GF (1985) A summary of waterborne illnesses transmitted through contaminated groundwater. Journal of Environmental Health 48, 122-127.

Crites RW, Tchobanoglous G (1998) 'Small and decentralized wastewater management systems.' (WCB/McGrawHill)

Cromer WC (2001) Treating domestic wastewater in a shallow coastal sand aquifer near Hobart. In ' Proceedings of On-site '01 Conference'. University of New England, Armidale, NSW pp. 113-120. (Lanfax Laboratories)

Daniel TC, Bouma J (1974) Column studies of soil clogging in a slowly permeable soil as a function of effluent quality. Journal of Environmental Quality 3, 321-326.

Davison L, Bayley M, Kohlenberg T, Craven J (2002) 'Performance of reed beds and single pass sand filters with characterisation of domestic effluent: NSW North Coast.' Research Report for NSW Department of Local Government's SepticSafe scheme.

Dawes L, Goonetilleke A (2001) Importance of site characteristics in designing effluent disposal areas. In 'Proceedings of On-site '01 Conference'. University of New England, Armidale, NSW pp. 133-140. (Lanfax Laboratories)

Dawes L, Goonetilleke A (2003) An investigation into the role of site and soil characteristics in onsite sewage treatment. Environmental Geology 44, 467-477.

Dawes L, Goonetilleke A (2004) Assessing changes in soil physical and chemical properties under long term effluent disposal. In 'Tenth National Symposium on Individual and Small Community Sewage Systems'. March 21-24, Sacramento, California. (Ed. KR Mankin) pp. 349-357. (ASAE, St Joseph, Michigan)

Day L (2004) Septic systems as potential pollution sources in the Cannonsville Reservoir watershed, New York. Journal of Environmental Quality 33, 1989-1996.

De Vries J (1972) Soil filtration of wastewater effluent and the mechanism of pore clogging. Journal of Water Pollution Control Federation 44, 565-573. 
DeBorde D, C., Woessner W, W., Lauerman B, Ball PN (1998) Virus occurrence and transport in a school septic system and unconfined aquifer. Ground Water 36, 825-834.

Dillon KS, Corbett DR, Chanton JP, Burnett WC, Furbish DJ (1999) The use of sulfur hexafluoride (SF $)_{6}$ as a tracer of septic tank effluent in the Florida Keys. Journal of Hydrology 220, 129-140.

Dillon KS, Corbett DR, Chanton JP, Burnett WC, Kump L (2000) Bimodal transport of a waste water plume injected into saline ground water of the Florida Keys. Ground Water 38, 624-634.

Edgar NB (1999) Land use in the Taupo catchment, New Zealand. New Zealand Journal of Marine and Freshwater Research 33, 375-383.

EPRI (2000) National Research Needs Conference Proceedings: Risk Based Decision Making for Onsite Wastewater Treatment. EPRI Palo Alto, CA, U.S. Environmental Protection Agency and National Decentralized Water Resources Capacity Development Project: 20011101446

Forrest JA, Beatty J, Hignett CT, Pickering J, Williams RGP (1985) 'A survey of the physical properties of wheatland soils in Eastern Australia.' Divisional Report No. 78, CSIRO Division of Soils.

Frankenberger WT, Troeh FR, Dumenil LC (1979) Bacteria effects on hydraulic conductivity of soils. Soil Science Society of America Journal 43, 333-338.

Frenzel S, Couvillion C (2002) Fecal-indicator bacteria in streams along a gradient of residential development. Journal of the American Water Resources Association 38, 265-273.

Gardner T, Geary P, Gordon I (1997) Ecological sustainability and on-site effluent treatment systems. Australian Journal of Environmental Management 4, 144-156.

Geary P (1992) Diffuse pollution from wastewater disposal in small unsewered communities. Australian Journal of Soil and Water Conservation 5, 28-33.

Geary P (1994) Soil survey and the design of wastewater disposal systems. Australian Journal of Soil and Water Conservation 7, 16-23.

Geary PM (2004) On-site domestic system effluent tracing in a coastal catchment. In 'Tenth National Symposium on Individual and Small Community Sewage Systems'. March 21-24, Sacramento, California. (Ed. KR Mankin) pp. 722-732. (ASAE, St Joseph, Michigan)

Geary PM, Davies CM (2004) Bacterial source tracking and shellfish contamination in a coastal catchment. Water Science and Technology 47, 95-100.

Geary PM, Gardner EA (1998) Sustainable on-site treatment systems. In 'On site wastewater treatment. Proceedings of the Eighth National Symposium on Individual and Small Community Sewage Systems, Orlando, Florida, USA'. ((ASAE); St Joseph; USA)

Gerritse RG (1993) Mobility of phosphate from wastewater in calcareous sands of Rottnest Island (WA). Australian Journal of Soil Research 31, 235-244.

Gerritse RG (2002) 'Movement of nutrients from onsite wastewater systems in soils.' Geoprocc Pty Ltd prepared for Department of Health, Western Australia, May 28, 2002.

Gerritse RG, Adeney JA, Dimmock GM, Oliver YM (1995a) Retention of nitrate and phosphate in soils of the Darling Plateau in Western Australia: Implications for domestic septic tank systems. Australian Journal of Soil Research 33, 353-367. 
Gerritse RG, Adeney JA, Hosking J (1995b) Nitrogen losses from a domestic septic tank system on the Darling Plateau in Western Australia. Water Research 29, 2055-2058.

Gibbs MM (1991) Nutrient concentration changes in the ground water beneath Taupo township following sewage reticulation. New Zealand Journal of Marine and Freshwater Research 25, 153-161.

Gilliom RJ, Patmont CR (1983) Lake phosphorus loading from septic systems by seasonally perched groundwater. Journal of Water Pollution Control Federation 55, 1297-1305.

Gold A, Sims J (2000) Research needs in decentralized wastewater treatment and management: A risk-based approach to nutrient contamination. National Research Needs Conference Proceedings: Risk Based Decision Making for Onsite Wastewater Treatment. EPRI Palo Alto, CA, U.S. EPA and National Decentralized Water Resources Capacity Development Project: 20011101446 p. 48

Gold AJ, Addy K, Kellogg DQ, Rosenblatt AE (1999) Nitrate removal in shallow groundwater. In 'Proceedings 10th Northwest On-site Wastewater Shortcourse, Univ. Washington, Seattle WA' pp. 211-231

Graves AK, Hagedorn C, Teetor A, Mahal M, Booth AM, Reneau RB (2002) Antibiotic resistance profiles to determine sources of fecal contamination in a rural Virginia watershed. Journal of Environmental Quality 31, 1300-1308.

Halliwell DJ, Barlow KM, Nash DM (2001) A review of the effects of wastewater sodium on soil physical properties and their implications for irrigation systems. Australian Journal of Soil Research 39, 1259-1267.

Hansen EC, Mansell RS (1986) Simulated unsaturated-saturated water flow from a septic tank drain to groundwater. Soil and Crop Science Society of Florida 45, 21-29.

Harman J, Robertson WD, Cherry JA, Zanini L (1996) Impacts on a sand aquifer from an old septic system: nitrate and phosphate. Ground Water 34, 1105-1114.

Harrison RB, Turner NS, Hoyle JA, Krejsl J, Tone DD, Henry CL, Isaksen PJ, Xue D (2000) Treatment of septic effluent for fecal coliform and nitrogen in coarse-textured soils: use of soil-only and sand filter systems. Water Air and Soil Pollution 124, 205-215.

Heisig P (2000) 'Effects of residential and agricultural land uses on the chemical quality of baseflow of small streams in the Croton Watershed, southeastern New York.' Water-Resources Investigations Report 99-4173, U.S Geological Survey: Reston, Virginia.

Higgins JJ, Heufelder G, Foss S (1999) Removal efficiency of standard septic tank and leach trench septic systems for MS2 Coliphage. In 'Proceedings 10th Northwest On-site Wastewater Shortcourse, Univ. Washington, Seattle $\mathrm{WA}^{\prime}$

Hill AR (1996) Nitrate removal in stream riparian zones. Journal of Environmental Quality 25, 743-755.

Hillel D (1980) 'Applications of soil physics.' (Academic Press, Inc.)

Hoxley G, Dudding M (1994) Groundwater contamination by septic tank effluent: two case studies in Victoria, Australia. In 'Water Down Under 94, 21-25 Nov 1994, Adelaide SA,' pp. 145-152. (Institution of Engineers Australia)

Huntzinger Beach DN, McCray JE (2003) Numerical modeling of unsaturated flow in wastewater soil absorption systems. Ground Water Monitoring and Remediation 23, 64-72.

Jacoby JM, Anderson CW, Welch EB (1997) Pine Lake response to diversion of wetland inflow. Lake and Reservoir Management 13, 302-314. 
813 Janni KA, Nye JC, Jones DD, Krutz GW, Yahner JE (1980) Finite element analysis of effluent flow from

814 subsurface sewage disposal fields. Transactions of the ASAE 23, 336-342.

815

Jelliffe PA (1999) Developments in determining critical lot density for the protection of water quality. In 'On-site '99. Proceedings of On-site '99 Conference: Making on-site wastewater systems work'. Univeristy of New England,Armidale, NSW. (Ed. A Patterson Robert) pp. 191-198. (Lanfax Laboratories)

Jelliffe PA, Sabburg G, Wolff J (1995) Key factors in minimising water pollution from unsewered areas. In 'Australian Water and Wastewater Association Federal Convention, 16th, 2- 6 Apr 1995, Sydney NSW, Proceedings' pp. 85-90. (Australian Water and Wastewater Association, Artarmon NSW)

Jenssen PD, Krogstad (1988) Particles found in clogging layers of wastewater infiltration systems may cause reduction in infiltration rate and enhance phosphorus absorption. Water Science and Technology 20, 251-253.

Jones A, Lee F (1979) Septic tank wastewater disposal systems as phosphorus sources for surface waters. Journal of Water Pollution Control Federation 51, 2764-2775.

Jones DS, Armstrong AQ, Mulheim MD, Sorensen BV (2000) Integrated risk assessment / risk management as applied to decentralized wastewater treatment: A high level framework. In 'National Research Needs Conference Proceedings: Risk Based Decision Making for Onsite Wastewater Treatment. EPRI Palo Alto, CA, U.S EPA and National Decentralized Water Resources Capacity Development Project: 2001 1101446'

Katz BG, Lindner JB, Ragone SE (1980) A comparison of nitrogen in shallow groundwater from sewered and unsewered areas. Nassau County, New York from 1952 through 1976. Ground Water 18, 607-616.

Kookana RS, Baskaran S, Naidu R (1998) Pesticide fate and behaviour in Australian soils in relation to contamination and management of soil and water: a review. Australian Journal of Soil Research 36, 715 - 764.

Kristiansen R (1981a) Sand-filter trenches for purification of septic tank effluent: I. The clogging mechanism and soil physical environment. Journal of Environmental Quality 10, 353-357.

Kristiansen R (1981b) Sand-filter trenches for purification of septic tank effluent: II. The fate of nitrogen. Journal of Environmental Quality 10, 358-361.

Kristiansen R (1981c) Sand-filter trenches for purification of septic tank effluent: III. The microflora. J Environ Qual 10, 361-364.

Kropf FW, Laak R, Healy KA (1977) Equilibrium operation of subsurface absorption systems. Journal of Water Pollution Control Federation 49, 2007-2016.

Laak R (1970) Influence of domestic wastewater pretreatment on soil clogging. Journal of Water Pollution Control Federation 42, 1495-1500.

Laak R (Ed.) (1986) 'Wastewater engineering design for unsewered areas (2nd edn).' (Technomic Publishing Co. Inc.) 
Leeming R (1998) Distinguishing sources of faecal pollution in Australian inland and coastal waters. In 'Microbial indicators of river health, 31 July-1Aug 1997, Macquarie University, Sydney NSW, Proceedings' pp. 29-31. (Land and Water Resources Research and Development Corporation Canberra ACT)

Leeming R, Ball A, Ashbolt NJ, Nichols PD (1996) Using faecal sterols from humans and animals to distinguish faecal pollution in receiving waters. Water Research 30, 2893-2900.

L'hirondel J, L'hirondel J-L (2002) 'Nitrate and man.' (CABI Publishing, UK)

Lipp EK, Farrah S, Rose JB (2001) Assessment and impact of microbial fecal pollution and human enteric pathogens in a coastal community. Marine Pollution Bulletin 42, 286-293.

Magdoff FR, Bouma J (1974) The development of soil clogging in sands leached with septic tank effluent. In ' Proceedings of the National Homesewage Disposal Symposium, 1974 .' pp. 37-47. (ASAE; St Joseph; USA)

Magdoff FR, Bouma J, Keeney DR (1974a) Columns representing mound-type disposal systems for septic tank effluent: I. Soil-water and gas relations. Journal of Environmental Quality 3, 223-228.

Magdoff FR, Keeney DR, Bouma J (1974b) Columns representing mound-type disposal systems for septic tank effluent: II. Nutrient transformations and bacterial populations. Journal of Environmental Quality 3, 228-233.

Mamedov AI, Levy GJ (2001) Clay dispersivity and aggregate stability effects on seal formation and erosion in effluent-irrigated soils. Soil Science 166, 631-639.

Martens DM, Geary PM (1999) Australian on-site wastewater strategies: A case study of Scotland Island, Sydney, Australia. In 'Proceedings of On-site '99 Conference'. University of New England, Armidale, NSW pp. 255-263. (Lanfax Laboratories)

McCardell A, Davison L (2003) Greywater attenuation in a basaltic soil. In 'Proceedings of On-site '03

Conference'. Armidale NSW. (Lanfax Laboratories)

McGauhney PH, Winneberger JH (1964) Studies of the failure of septic tank percolation systems. Journal of Water Pollution Control Federation 36, 593-606.

McGuinness RI, Martens DM (2003) GIS-based model to assess potential risk of individual on-site effluent management systems - development assessment module (DAM). In 'Proceedings of On-site '03 Conference'. University of New England, Armidale, NSW. (Lanfax Laboratories)

Menzies NW, Skilton JA, Guppy CN (1999) Phosphorus storage on effluent irrigated land. Journal of Environmental Quality 28, 750-754.

Moore JW, Scheuerell MD, Frodge J (2003) Lake eutrophication at the urban fringe, Seattle region, USA. Ambio 32, 13-18.

Oakley S, Greenwood WP, Lee M (1999) Monitoring nitrogen and virus removal in the vadose zone with suction lysimeters. In 'Proceedings 10th Northwest On-site Wastewater Shortcourse, Univ. Washington, Seattle WA'

Otis RJ (1984) Soil clogging:mechanisms and control. In 'On site wastewater treatment. Proceedings of the Fourth National Symposium on Individual and Small Community Sewage Systems, New Orleans, Louisiana, USA' pp. 238-251. ((ASAE); St Joseph; USA)

Otis RJ (1991) Demythologizing the septic tank. In 'On site wastewater treatment. Proceedings of the Sixth National Symposium on Individual and Small Community Sewage Systems, Chicago, Illinios, USA' pp. 1-6. ((ASAE); St Joseph; USA) 
923 Pang L, Close M, Goltz M, Sinton L, Davies H, Hall C, Stanton G (2003) Estimation of septic tank setback

Patterson RA (2001) Wastewater quality relationships with reuse options. Water Science and Technology 43, 147154.

Paul JH, Rose JB, Brown J, Shinn E, Miller S, Farrah S (1995) Viral tracer studies indicate contamination of marine waters by sewage disposal practices in Key Largo, Florida. Applied and Environmental Microbiology 61, 2230-2234.

Pell M, Nyberg F (1989a) Infiltration of wastewater in a newly started pilot sand-filter system: I. Reduction of organic matter and phosphorus. Journal of Environmental Quality 18, 451-457.

Pell M, Nyberg F (1989b) Infiltration of wastewater in a newly started pilot sand-filter system: III. Transformation of nitrogen. Journal of Environmental Quality 18, 463-467.

Perkins RJ (1984) Septic tanks, lot size and pollution of water table aquifers. Journal of Environmental Health 46, 298-304.

Ponnamperuma FN (1972) The chemistry of submerged soils. Advances in Agronomy 24, 29 - 96.

Postma D, Boesen C, Kristiansen H, Larsen F (1991) Nitrate reduction in an unconfined aquifer: water chemistry, reduction processes, and geochemical modelling. Water Resources Research 27, 2027-2045.

Postma FB, Gold AJ, Loomis GW (1992) Nutrient and microbial movement from seasonally-used septic systems. Journal of Environmental Health 55, 5-10.

Potts DA, Gorres JH, Nicosia EL, Amador JA (2004) Effects of aeration on water quality from septic system leachfields. Journal of Environmental Quality 33, 1828-1838.

Powelson DK, Mills AL (2001) Transport of Escherichia coli in sand columns with constant and changing water contents. Journal of Environmental Quality 30, 238-245.

Powelson DK, Simpson JR, Gerba CP (1990) Virus transport and survival in saturated and unsaturated flow through soil columns. Journal of Environmental Quality 19, 396-401.

Ptacek CJ (1998) Geochemistry of a septic-system plume in a coastal barrier bar, Point Pelee, Ontario, Canada. Journal of Contaminant Hydrology 33, 293-312.

Rahe TM, Hagedorn C, McCoy EL, Kling GF (1978) Transport of antibiotic resistant Escherichia coli through western Orgeon hillslope soils under saturated flow. Journal of Environmental Quality 7, 487-494.

Redding MR, A B, Gardner T, Duperouzel D (2002) An overview of land application of pig effluent-P using soil P chemistry and mass balance calculations. Australian Journal of Soil Research 40, 81-91.

Reneau RB, Elder JH, Pettry DE, Weston CW (1975) Influence of soils on bacterial contamination of a watershed from septic sources. Journal of Environmental Quality 4, 249-252.

Reneau RB, Pettry DE (1975) Movement of coliform bacteria from septic tank effluent through selected coastal plain soils of Virginia. Journal of Environmental Quality 4, 41-44.

Rice RC (1974) Soil clogging during infiltration of secondary effluent. Journal of Water Pollution Control Federation 46, 708-716.

Robertson WD, Blowes DW, Ptacek CJ, Cherry JA (2000) Long-term performance of in situ reactive barriers for 978 nitrate remediation. Ground Water 38, 689-695. 
979

980

981

982

983

984

985

986

987

988

989

990

991

992

993

994

995

996

997

998

999

1000

1001

1002

1003

1004

1005

1006

1007

1008

1009

1010

1011

1012

1013

1014

1015

1016

1017

1018

1019

1020

1021

1022

1023

1024

1025

1026

1027

1028

1029

1030

1031

1032

1033
Robertson WD, Cherry JA, Sudicky EA (1991) Ground-water contamination from two small septic systems on sand aquifers. Ground Water 29, 82-92.

Robertson WD, Harman J (1999) Phosphate plume persistence at two decommissioned septic system sites. Ground Water 37, 228-236.

Ronner AB, Wong ACL (1998) Characterization of microbial clogging in wastewater infiltration systems. In 'Proceedings of the Eighth National Symposium on Individual and Small Community Sewage Systems'. Orlando, Florida pp. 37-42. (ASAE; St Joseph; USA)

Ryan v Great Lakes Council (1999) Federal Court of Australia, 177 (5 March 1999).

Siegrist R (1987) Soil clogging during subsurface wastewater infiltration as affected by effluent composition and loading rate. Journal of Environmental Quality 16, 181-187.

Siegrist R, Boyle WC (1987) Wastewater-induced soil clogging development. Journal of Environmental Engineering 113, 550-566.

Siegrist R, Hargett DL, Anderson DL (1983) Vadose zone effects on the performance of large subsurface wastewater absorption systems. In 'Proceedings on Characterization and Monitoring of the Vadose (unsaturated zone)'. Las Vegas NV, National Water Well Association, Worthington OH, pp 223-242

Siegrist R, Smed-Hildmann R, Filip ZK, Jenssen PD (1991) Humic substances formation during wastewater infiltration. In 'Proceedings of the Sixth National Symposium on Individual and Small Community Sewage Systems'. Chicago, IL pp. 223-232. (ASAE; St Joseph)

Siegrist R, Tyler EJ, Jenssen PD (2000) Design and performance of onsite wastewater soil absorption systems. National Research Needs Conference Proceedings: Risk Based Decision Making for Onsite Wastewater Treatment. EPRI Palo Alto, CA, U.S. Environmental Protection Agency and National Decentralized Water Resources Capacity Development Project: 20011101446 p. 48

Siegrist R, Van Cuyk S (2001) Wastewater soil absorption systems: The performance effects of process and environmental conditions. In 'Proceedings of the Ninth National Symposium on Individual and Small Community Sewage Systems'. Fort Worth, Texas pp. 41-51. (ASAE; St Joseph)

Standards Australia (1994) 'AS 1547: 1994 - Disposal systems for effluent from domestic premises.' Standards Association of Australia, NSW.

Standards Australia, Standards New Zealand (2000) 'AS/NZS 1547:2000 On-site domestic wastewater management.' (Jointly published by Standards Australia International Ltd, NSW and Standards New Zealand, Wellington)

Starr JL, Sawhney BL (1980) Movement of nitrogen and carbon from a septic system drainfield. Water Air and Soil Pollution 13, 113-123.

Steffy LY, Kilham S (2004) Elevated $\delta 15^{\mathrm{N}}$ in stream biota in areas with septic tank systems in an urban watershed. Ecological Applications 14, 637-641.

Stevik TK, Ausland G, Jenssen PD, Siegrist R (1999) Removal of E.coli during intermittent filtration of wastewater effluent as affected by dosing rate and media type. Water Research 33, 2088-2098.

Stewart LW, Reneau RB, Jr. (1988) Shallowly placed, low pressure distribution system to treat domestic wastewater in soils with fluctuating high water tables. Journal of Environmental Quality 17, 499-504. 
Tuthill A, Meikle D, Alavanja M (1998) Coliform bacteria and nitrate contamination of wells in major soils of Frederick, Maryland. Journal of Environmental Health 60, 16-20.

Tyler EJ, Converse JC (1994) Soil acceptance of onsite wastewater as affected by soil morphology and wastewater quality. In 'Proceedings of the Seventh National Symposium on Individual and Small Community Sewage Systems'. Atlanta, GA pp. 185-194. (ASAE; St Joseph)

Uebler RL (1984) Effect of loading rate and soil amendments on inorganic nitrogen and phosphorus leached from a wastewater soil absorption system. Journal of Environmental Quality 13, 475-479.

USEPA (1977) 'Waste disposal practices and their effects on ground water. Report to Congress, January, 1977, Washington DC, USA, 512pp.'

USEPA (1997) 'Response to Congress On Use of Decentralized Wastewater Treatment Systems. USEPA publication EPA/832/R-97/001b. U.S. Environmental Protection Agency, Office of Water, Washington, DC.'

USEPA (2002) 'Onsite wastewater treatment systems manual.' Office of Research and Development, US Environmental Protection Agency EPA/625/R-00/008, February.

Valiela I, Collins G, Kremer J, Lajtha K, Geist M, Seely B, Brawely J, Sham CH (1997) Nitrogen loading from coastal watersheds to receiving estuaries: New method and application. Ecological Applications 7, 358-380.

Valiela I, Costa JE (1988) Eutrophication of Buttermillk Bay, a Cape Cod Coastal embayment: Concentrations of nutrients and watershed nutrient budgets. Environmental Management 12, 539-553.

van Cuyk S, Siegrist R (2001) Pathogen fate in wastewater soil absorption systems as affected by effluent quality and soil clogging genesis. In ' Proceedings of the Ninth National Symposium on Individual and Small Community Sewage Systems'. Fort Worth, Texas pp. 125-135. (ASAE; St Joseph; USA)

van Cuyk S, Siegrist R, Logan A (2001a) Evaluation of virus and microbial purification in wastewater soil absorption systems using multicomponent surrogate and tracer additions. In ' Proceedings of the Ninth National Symposium Individual and Small Community Sewage Systems' pp. 30-40. (ASAE; St Joseph; USA)

van Cuyk S, Siegrist R, Logan A, Masson S, Fischer E, Figueroa L (2001b) Hydraulic and purification behaviours and their interactions during wastewater treatment in soil infiltration systems. Water Research 35, 953-964.

van Cuyk S, Siegrist RL, Lowe K, Harvey R (2004) Evaluating microbial purification during soil treatment of wastewater with multicomponent tracer and surrogate tests. Journal of Environmental Quality 33, 316-329.

Vaughn JM, Landry EF, McHarrell TZ (1983) Entrainment of viruses from septic tank leach fields through a shallow, sandy soil aquifer. Applied and Environmental Microbiology 1983, 1474-1480.

Walker WG, Bouma J, Keeney DR, Magdoff FR (1973a) Nitrogen transformations during subsurface disposal of septic tank effluent in sands. i. soil transformations. Journal of Environmental Quality 2, 475-480.

Walker WG, Bouma J, Keeney DR, Olcott PG (1973b) Nitrogen transformations during subsurface disposal of septic tank effluent in sands. ii. ground water quality. Journal of Environmental Quality 2, 521-525.

Weintraub L, Chen C, Tsai W, Herr J, Goldstein R, Siegrist R (2002) Modifications of WARMF to assess the efficacy of onsite wastewater systems on public health. In 'WEFTEC 2002, Chicago, IL, September 28 - October 2, 2002'

1088 
Weiskel PK, Howes BL (1992) Differential transport of sewage-derived nitrogen and phosphorus through a coastal watershed. Environmental Science and Technology 26, 352-360.

Weiskel PK, Howes BL, Heufelder G (1996) Coliform contamination of a coastal embayment: sources and transport pathways. Environmental Science and Technology 30, 1872-1881.

Whelan BR, Barrow NJ (1984a) The movement of septic tank effluent through sandy soils near Perth: I. Movement of nitrogen. Australian Journal of Soil Research 22, 283-292.

Whelan BR, Barrow NJ (1984b) The movement of septic tank effluent through sandy soils near Perth: II. Movement of phosphorus. Australian Journal of Soil Research 22, 293-302.

Whelan BR, Parker WF (1981) Bacterial and chemical transmission through sand: a field study in groundwater pollution form a septic tank in Perth, Western Australia. In 'Groundwater resources of the Swan Coastal Plain'. (Ed. BR Whelan) pp. 313-333. (CSIRO Aust. Perth)

Whelan BR, Titamnis ZV (1982) Daily chemical variability of domestic septic tank effluent. Water Air and Soil Pollution 17, 131-139.

Whitehead JH, Geary PM (2000) Geotechnical aspects of domestic on-site effluent management systems. Australian Journal of Earth Sciences 47, 75-82.

Whitehead JH, Geary PM, Saunders M (2001) Towards a better understanding of sustainable lot density evidence from five Australian case studies. In 'On-site '01: Proceedings of On-site '01 Conference'. University of New England, Armidale, NSW pp. 383-390. (Lanfax Laboratories)

Whitehead JH, Geary PM, Saunders M, Robertson G, Barry M, Syme W (2003) GIS-based risk assessment for catchment scale on-site wastewater management. In 'Proceedings of On-site '03 Conference:'. University of New England, Armidale, NSW. (Lanfax Laboratories)

Wilhelm SR, Schiff SL, Cherry JA (1994b) Biogeochemical evolution of domestic waste water in septic systems: 1. Conceptual model. Ground Water, 905-916.

Wilhelm SR, Schiff SL, Robertson WD (1994a) Chemical fate and transport in a domestic septic system: unsaturated and saturated zone geochemistry. Environmental Toxicology and Chemistry 13, 193-23.

Wilhelm SR, Schiff SL, Robertson WD (1996) Biogeochemical evolution of domestic waste water in septic systems: 2. application of conceptual model in sandy aquifers. Ground Water 34, 853-864.

Yates MV (1985) Septic tank density and ground-water contamination. Ground Water 23, 586-591.

Yates MV, Yates SR (1988) Modeling microbial fate in the subsurface environment. Critical Reviews in Environmental Science and Technology 17, 307-345.

Zanini L, Robertson WD, Ptacek CJ, Schiff SL, Mayer T (1998) Phosphorus characterization in sediments impacted by septic effluent at four sites in central Canada. Journal of Contaminant Hydrology 33, 405-429. 

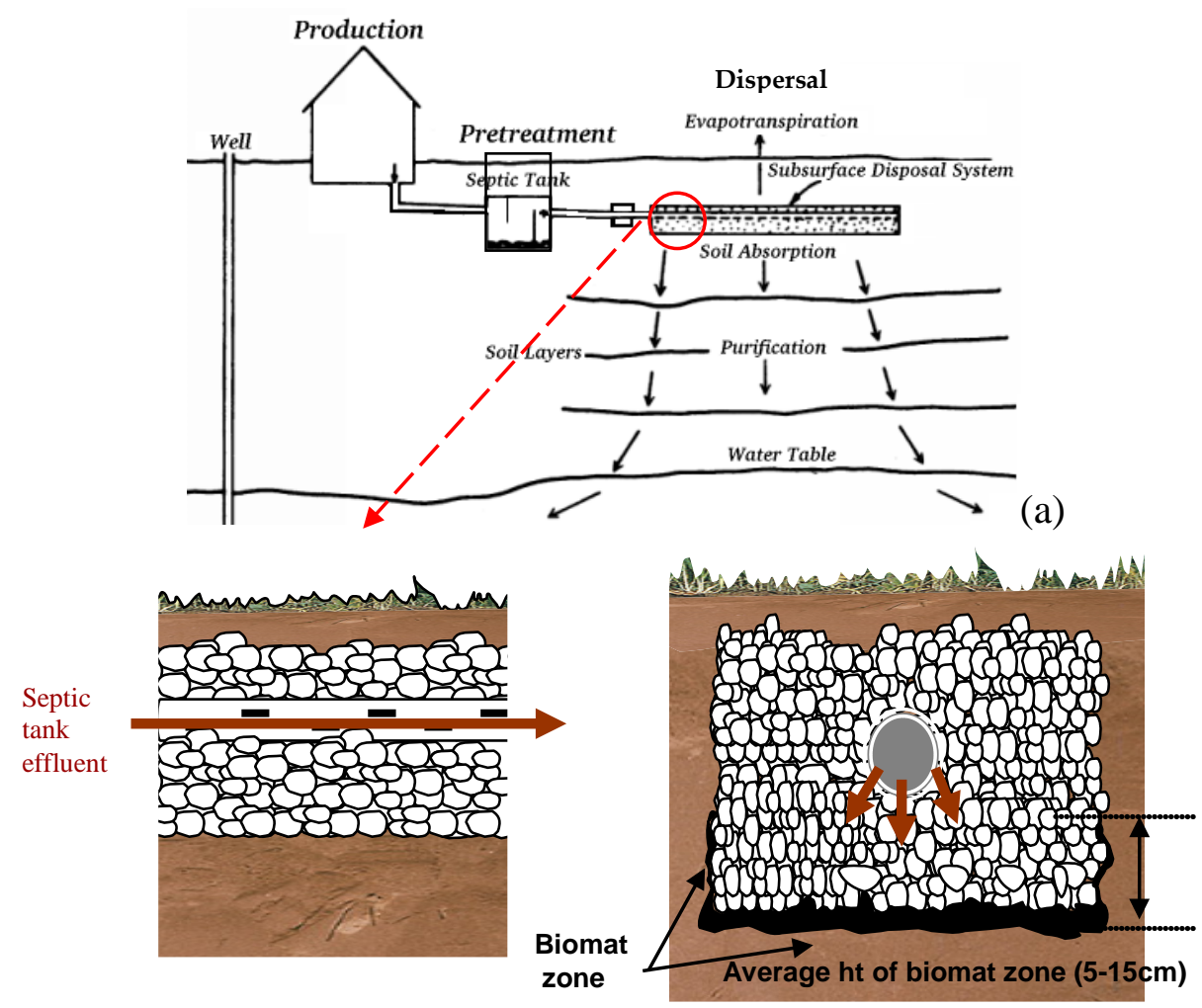

(b) Plan view of distribution pipe in gravel trench

(c) Cross section of distribution pipe in gravel trench 


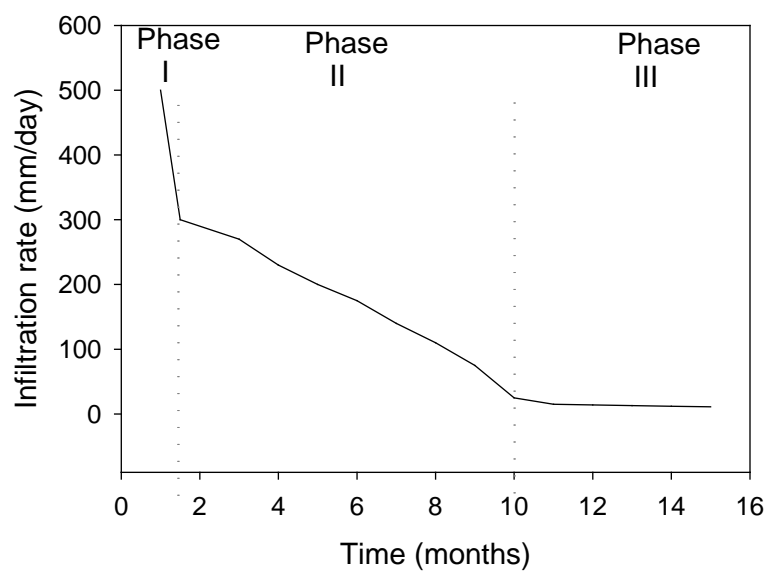

1145

1146 
1156 
Soil absorption systems: processes and performance

1157

1158

1159

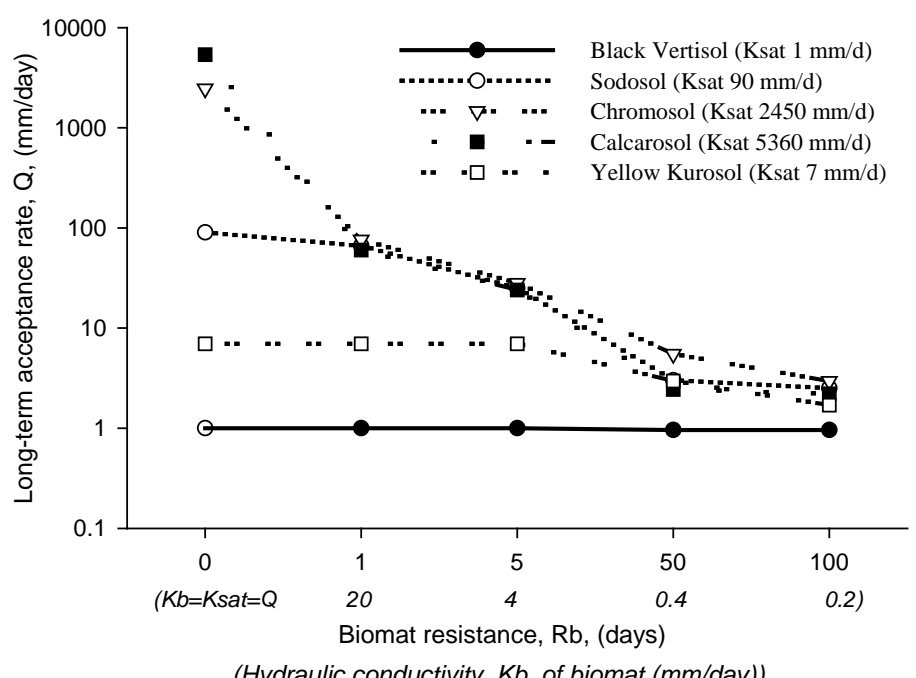

1160

1161

1162 
1163
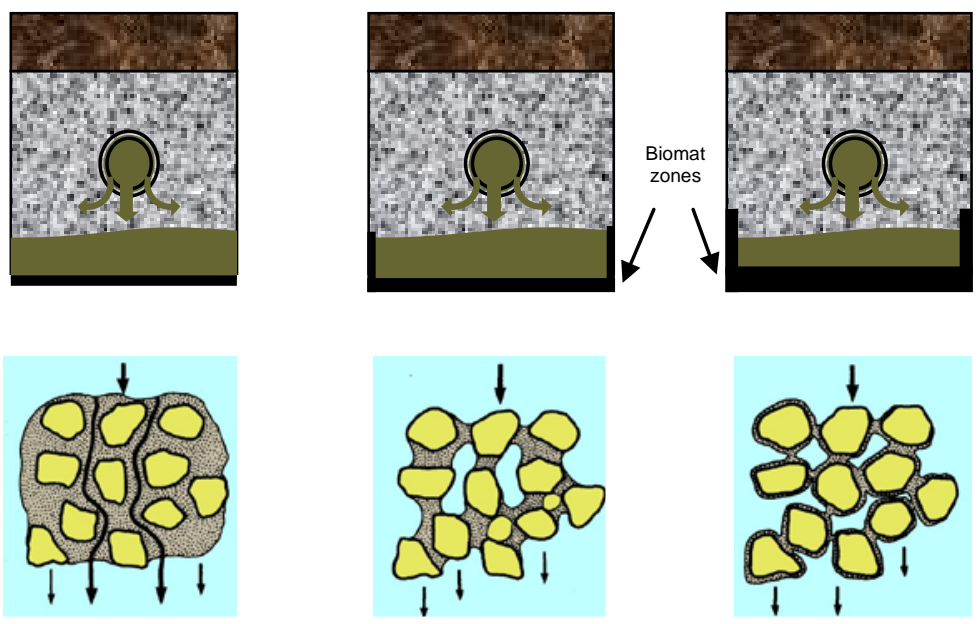

1164

1165

1166 
Table 1. Septic tank effluent quality for key pollutants

\begin{tabular}{ccccc}
\hline Effluent Parameter & $\begin{array}{c}\text { (Whelan and } \\
\text { Titamnis 1982) }\end{array}$ & $\begin{array}{c}\text { Beavers and } \\
\text { Gardner } \\
(1993)\end{array}$ & $\begin{array}{c}\text { Gardner } \text { et al. } \\
(1997)\end{array}$ & $\begin{array}{c}\text { Charles } \text { et al. } \\
(2004)^{\mathrm{A}}\end{array}$ \\
\hline BOD $_{5}(\mathrm{mg} / \mathrm{L})$ & $52-316$ & $150-180$ & $120-180$ & 224 \\
Suspended solids $(\mathrm{mg} / \mathrm{L}$ & $22-47$ & $100-180$ & $40-190$ & 379 \\
Total N (mg/L) & $74-237$ & $50-60$ & $40-50$ & 160 \\
Total P (mg/L) & $12.3-26$ & $10-15$ & $10-15$ & 21 \\
Faecal coliforms & - & $10^{5}-10^{7}$ & $10^{5}-10^{7}$ & $10^{6 \mathrm{~B}}$ \\
(cfu/100mL) & & & & \\
\hline
\end{tabular}




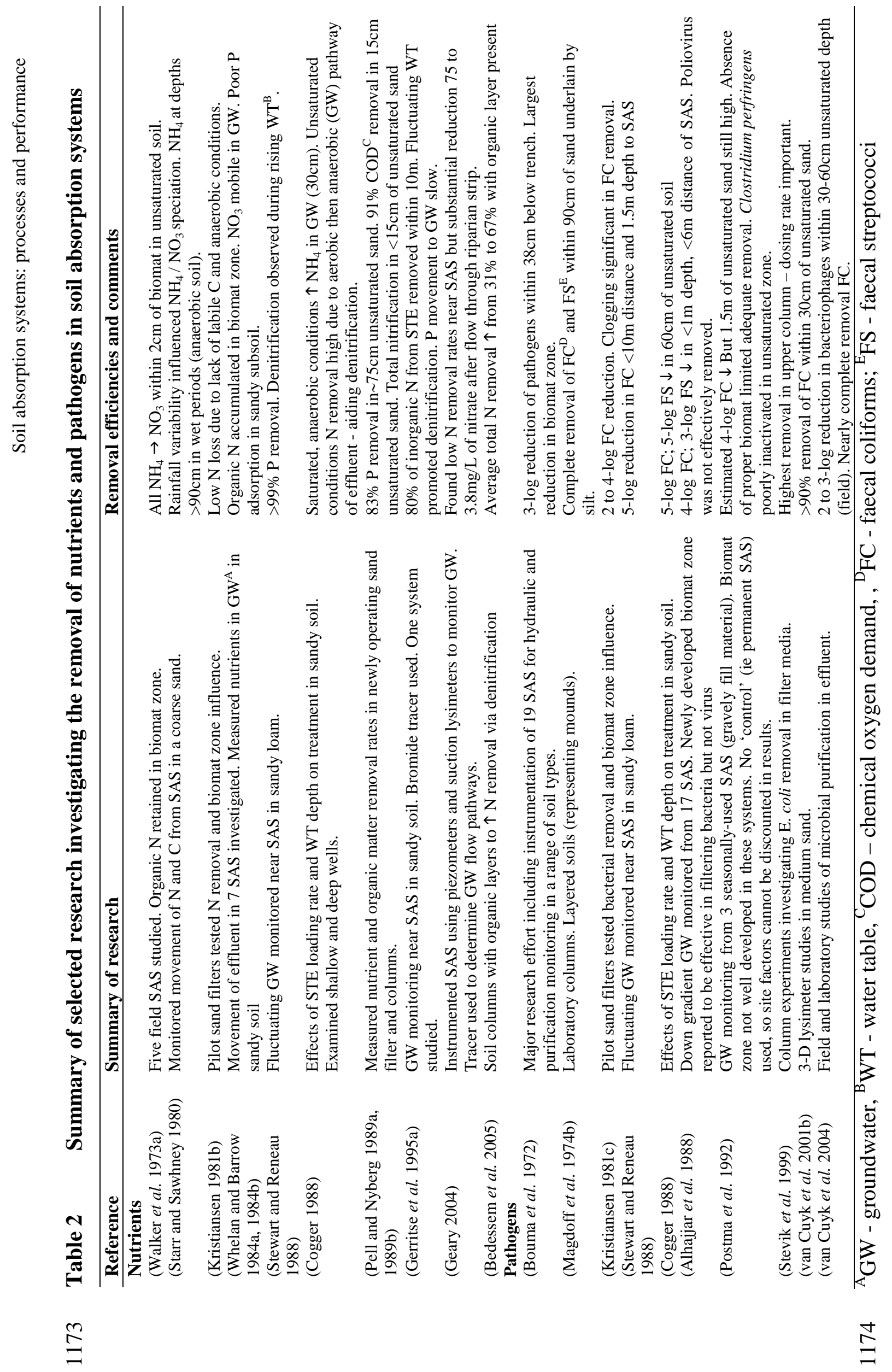




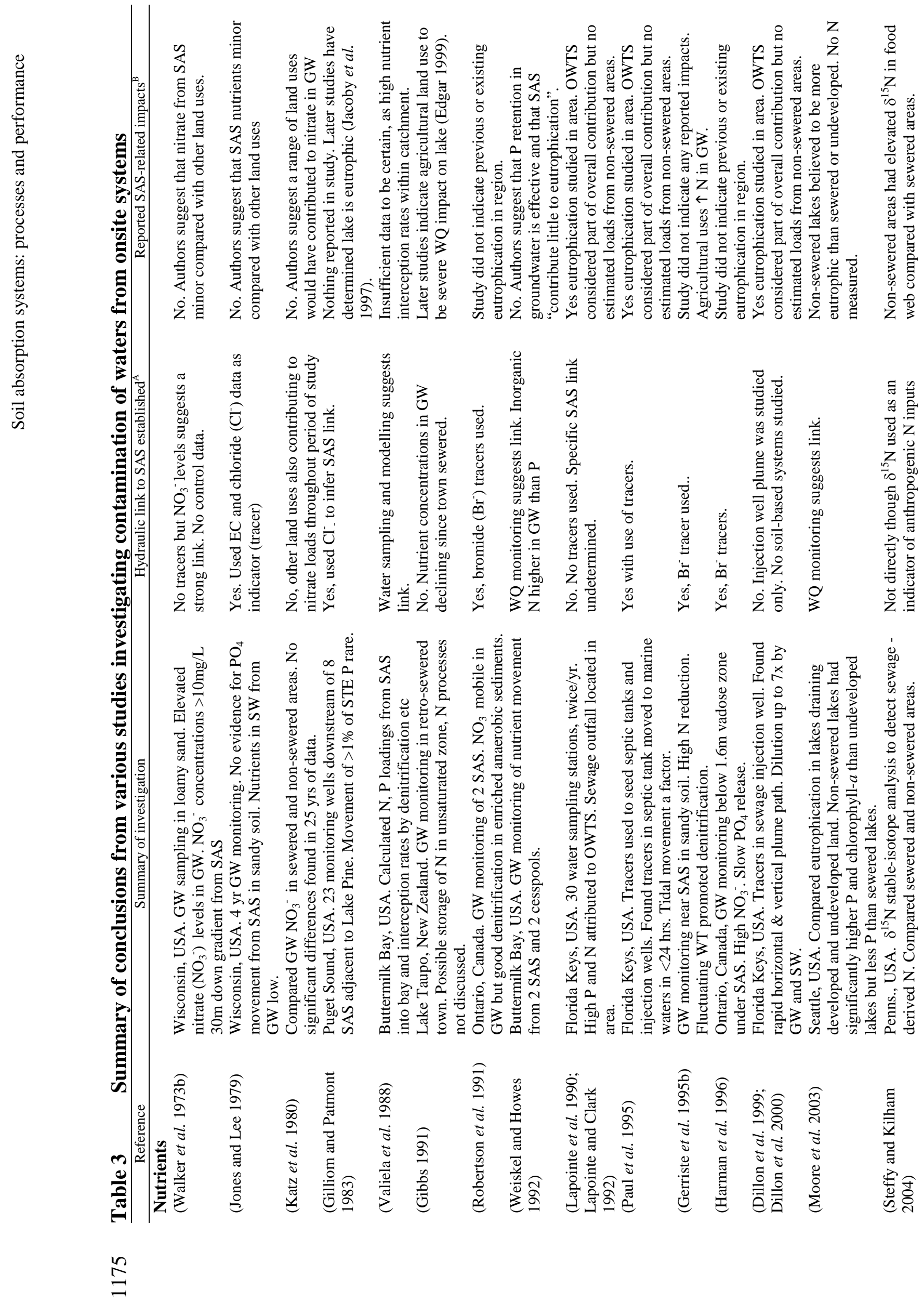




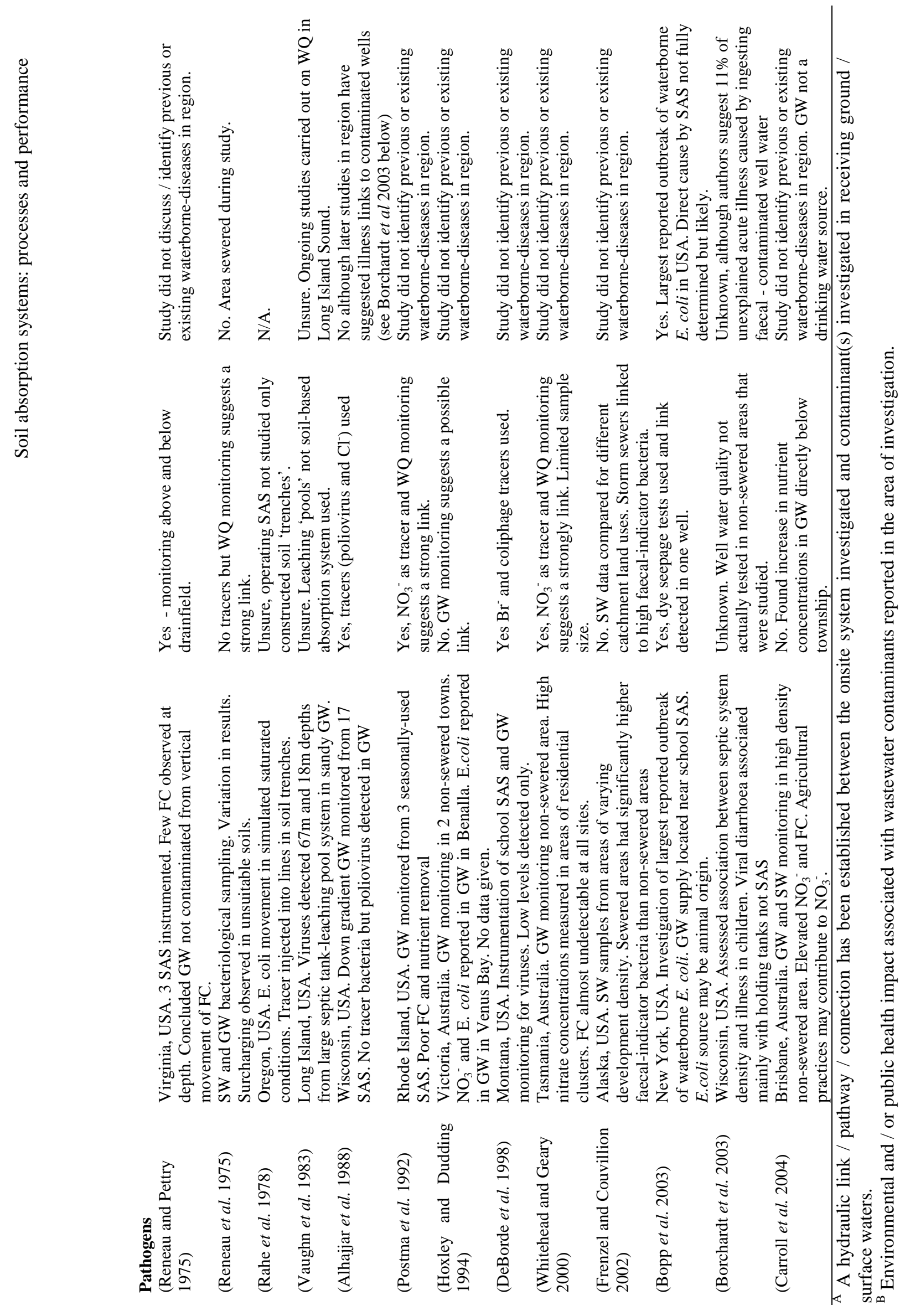

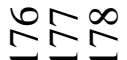


Table 4. Summary of some reported minimum sustainable lot sizes and OWTS densities

\begin{tabular}{cclc}
\hline $\begin{array}{c}\text { Lot size } \\
\left(\mathrm{m}^{2}\right)\end{array}$ & $\begin{array}{c}\text { System density } \\
\left(\text { per km } \mathrm{k}^{2}\right)\end{array}$ & \multicolumn{1}{c}{ Comments } & Reference \\
\hline 65,000 & 15 & $\begin{array}{l}\text { Septic system density considered potential for ground water } \\
\text { contamination }\end{array}$ & (USEPA 1977) \\
$2000-$ & $500-250$ & $\begin{array}{l}\text { Simple modelling showed increased N concentration below } \\
\text { SAS as lot size decreased } \\
4000\end{array}$ & (Perkins 1984) \\
$1000-$ & $1000-85$ & $\begin{array}{l}\text { Range of densities where ground water contamination had } \\
\text { been reported } \\
\text { Example density for NSW coastal town based on minimum } \\
\text { assimilative buffer area for pollutants (N, P, pathogens) } \\
12,000\end{array}$ & (Yates 1985) \\
10,000 & 100 & $\begin{array}{l}\text { Based on average nutrient and hydraulic loadings from 1999) } \\
\text { OWTS and minimum setback distances for pathogens } \\
\text { Recommended in environmentally sensitive areas based on } \\
\text { N and P assimilation }\end{array}$ & $\begin{array}{l}\text { (Geary and } \\
\text { (Gerritse 2002) }\end{array}$ \\
$2000-$ & $500-250$ & & \\
$50,000-$ & $10-20$ & &
\end{tabular}

Table 5. Summary of some key areas of further OWTS research

\begin{tabular}{ll}
\hline \multicolumn{1}{c}{ Site-scale } & \multicolumn{1}{c}{ Catchment-scale } \\
\hline Effects of pressure dosing on LTAR & Risk-based decision models e.g further validation of \\
for in Australian soils & OSRAS, DAM \\
Oxygen dynamics under biomat zone & Quantifying contaminant loads from on-site systems \\
Denitrification in SAS and technologies for & $\begin{array}{l}\text { Sustainable on-site system densities and separation } \\
\text { distances }\end{array}$ \\
removal of N & Monitoring sewered v non-sewered catchments - \\
Treatment capacities of a greater range of soil & looking for the “smoking gun” \\
types in Australia, e.g c colder climates & Role of riparian zone and fluctuating water tables in \\
Effects of pre-treated effluent and innovative & nitrate removal and P sorption in sediments \\
soil-based designs & Use of tracers to identify contaminant pathways in \\
Predicting biomat zone development and its role & surface and groundwaters \\
in long term effluent treatment / hydraulics &
\end{tabular}


1187 Fig. 1. Schematic representation of system layout and main processes (a); plan and cross section view

1188 of the trenches in a soil absorption system (b \& c).

1189

1190 Fig. 2 A commonly observed schematic pattern of wastewater infiltration rate decline through soil

1191 infiltrative surface over time, adapted from Otis (1984).

1192

1193 Fig. 3. Definition diagram of Equation 2. $\theta \mathrm{u}$ is the volumetric water content of the underlying soil

$1194\left(\mathrm{~cm}^{3} / \mathrm{cm}^{3}\right), \theta$ s is the saturated volumetric water content of the underlying soil $\left(\mathrm{cm}^{3} / \mathrm{cm}^{3}\right)$, z is soil depth

1195 (cm), and $\Psi \mathrm{u}$ is the soil moisture potential of the underlying soil

1196

1197 Fig. 4. Predicted effect of increasing $R_{b}$ on steady-state flow rates for a range of Australian soils (Beal

1198 et al. 2004a) (Note: $\mathrm{X}$ axis not to scale)

1200 Fig. 5. Cross section of trench with increasingly resistant biomat zone (top) resulting in increasingly 1201 unsaturated flow (below). 